\title{
LOS HIJOS DE MARTA LAS ÓRDENES MILITARES Y LAS TIERRAS DE LA MANCHA EN EL SIGLO XII
}

por

\author{
FRANCISCO RUIZ GÓMEZ \\ Universidad de Castilla-La Mancha
}

RESUMEN: El título del trabajo, "Los hijos de Marta», viene dado por las palabras de San Bernardo, quien en su "De laude novae militiae» recuerda el pasaje evangélico de Marta y María y compara su comportamiento en la defensa de Cristo, con la de los caballeros templarios y los monjes cistercienses respectivamente. Dicha imagen, ignorada por los bistoriadores de boy, tuvo una amplia difusión en la época, como lo demuestra el becho de que también fuera recogida en una bula librada por el papa Honorio III el año 1221 a favor de la orden de Calatrava.

Por otra parte, la fundación de las órdenes militares hispánicas y la creación de sus respectivos dominios en los siglos XII y XIII, estuvo relacionada con la conquista de las «extremaduras» $y$ la primera repoblación de estas tierras. Nuestro trabajo se ocupa preferentemente de la zona de la Mancha, por lo que nos referimos en él a la bistoria de las órdenes militares de Calatrava, Santiago y San Juan, y a sus respectivas cabeceras en el reino de Castilla, de Calatrava, Uclés y Consuegra. El estudio de la documentación de órdenes, junto con la consideración de la evolución de los paisajes y los datos incipientes del registro arqueológico, nos han permitido analizar de forma renovadora el progreso de la repoblación y, asimismo, bemos podido precisar y cuantificar su alcance, lo que se resume en los siguientes datos: Ocupación de un territorio de unos $30.000 \mathrm{~km}^{2}$, sobre el que se extiende una red de unos 40 castillos, con 1.600 bombres de armas aproximadamente, y más de cien villas, habitadas por un número indeterminado de caballeros, peones, labradores y pastores.

PAlabras Clave: Órdenes Militares. Caballería. La Mancha. Repoblación siglos XII-XIII.

ABSTRACT: The title of this article is derived from the words of St. Bernard's, who in bis "De Laude Novae Militiae» reminds us of a Biblical passage describing Martha and Mary, and compares their bravery in the defence of Jesus with that of the Knights Templar and the Cistercians respectively. This image, unknown to bistorians to- 


\begin{abstract}
day, enjoyed wide circulation at the time, as witnessed by the fact that it was noted in a bull delivered by Pope Honorius III in 1221 to the Order of Calatrava.

The foundation of the Iberian military orders and the creation of their respective domains in the twelfth and thirteenth centuries were closely connected to the conquest of Extremaduras and the first repopulation of those lands. This article focuses on the region of La Mancha, and correspondingly with the bistory of the military orders of Calatrava, Santiago and San Juan a well as to their respective Castilian bases, namely Calatrava, Uclés and Consuegra. The study of documents concerning the orders, together with consideration of the evolution of landscapes and preliminary archaeological data, allow us to approach the process of repopulation in a new light, and to specify and quantify its progress. This can be summarised thus: occupation of a territory of about 30.000 square kilometres, a network of 40 castles, peopled by approximately 1.600 men-at-arms, and over one bundred towns, inhabited by an indeterminate number of knights, squires, labourers and shepherds.
\end{abstract}

KEY WORDS: Military Orders. Repopulation. Chivalry. La Mancha (Spain) XII and XIII centuries).

El presente trabajo estudia los primeros tiempos de la historia de las Órdenes Militares de Calatrava, Santiago y San Juan y su asentamiento en tierras de la Mancha. El título que hemos elegido se debe a que los caballeros de estos institutos, de modales rudos y violentos, fueron comparados en alguna ocasión con los hijos de Marta, en recuerdo de aquella mujer del Evangelio, hermana de Lázaro, que se esforzó en servir a Jesús quizá hasta el exceso y tuvo, al mismo tiempo, la fortaleza necesaria para doblegar al dragón, según el imaginario colectivo medieval. Su actitud resolutiva, su amor y su fidelidad se entendieron como un digno contrapunto del recato y la mansedumbre de los monjes, muy probablemente los cistercienses, que integrarían entonces el grupo de los hijos de María, para componer todos juntos una misma comunidad de monjes y soldados encargados de la defensa de la fe y la alabanza divina. Por otra parte, el despliegue de las Órdenes Militares en la España del siglo XII fue una fenómeno paralelo al progreso de la Reconquista y primera repoblación de la transierra y las extremaduras castellano-leonesa por esa misma época, y se relacionó de forma más directa con la conquista cristiana del Reino de Toledo y las tierras de la llanura de la Mancha entre 1085 y 1226.

Nuestro trabajo es en gran parte fruto de la consulta directa de la riquísima documentación existente en los archivos españoles sobre la conquista de la Mancha en el siglo XII y la fundación de las Órdenes Militares y al mismo tiempo una síntesis crítica de los resultados de numerosas investigaciones precedentes, realizadas especialmente a partir de la publicación de la obra de J. González ${ }^{1}$ sobre Castilla la Nueva, y las investigaciones de J. O'Callaghan ${ }^{2}$,

\footnotetext{
${ }^{1}$ GonZÁleZ, J. Repoblación de Castilla La Nueva. Madrid 1975, 2 vols.

2 O'Callaghan, J. The Spanish Military Order of Calatrava and its Affiliates. Variorum Reprints. Londres 1975.
} 
J.L. Martín 3 y D. Lomax ${ }^{4}$ sobre las milicias de Calatrava y Santiago respectivamente. Nos proponemos analizar, en consecuencia, dos temas clásicos del medievalismo como son la repoblación de las extremaduras y la historia de las Órdenes Militares peninsulares; aunque al mismo tiempo pretendemos realizar una nueva aportación a la historiografía regional, en tanto que revisamos algunas de las tesis tradicionales 5 a la luz de la observación directa de la geografía de la Mancha y la consulta exhaustiva de las fuentes principales. Como resultado ofrecemos un estudio de la conquista de las tierras de la Mancha que amplía los datos hasta ahora conocidos y nos permite profundizar en el estudio de la labor repobladora desarrollada en los señoríos de las Órdenes Militares ${ }^{6}$. Al mismo tiempo es nuestro propósito aportar nueva luz al conocimiento de fenómenos de interés general, como fueron la extensión de la economía ganadera antes de la Mesta, y el desarrollo social y las relaciones económicas en un período de crecimiento y expansión de las sociedades hispanocristianas medievales.

Las fuentes más importantes para nuestro propósito son las crónicas y la documentación de Órdenes. Entre las crónicas de la época relacionadas con nuestro trabajo cabe mencionar la Cronica Adefonsi Imperatoris ${ }^{7}$, en especial su libro II que contiene el relato pormenorizado de la conquista de los Montes de Toledo y las tierras de la Mancha a mediados del siglo XII. La Historia de Rebus Hispaniae del arzobispo de Toledo D. Rodrigo Ximenez de Rada ${ }^{8}$ nos interesa

${ }^{3}$ Martín Rodríguez, J.L. Orígenes de la Orden Militar de Santiago (1170-1195). Barcelona 1975.

${ }^{4}$ Lomax, D. La Orden de Santiago (1170-1275). Madrid 1965.

5 Sobre la historia medieval de la Mancha, además de la obra de J. González, ya referida, pueden verse las propuestas de Reina Pastor sobre las formaciones sociales de la frontera: PASTOR, $R$. «Poblamiento, frontera y estructura agraria en Castilla la Nueva (1085-1230)» en Cuadernos de Historia de España 47-48 (1968) pp. 171-255. PASTOR, R. Del Islam al Cristianismo. En la frontera de dos formaciones económico- sociales. Toledo siglos X-XIII. Barcelona 1975. Y las de Ricardo Izquierdo que remiten ya al espacio de la actual Comunidad Autónoma de Castilla-La Mancha: IZQUIERDO BENITO, R. Castilla-La Mancha en la Edad Media. Toledo 1985.

${ }^{6}$ La bibliografía reciente sobre Órdenes Militares es extensísima, los trabajos más importantes en relación con los señoríos de estos institutos en la Mancha en la época que nos ocupa son: RiverA GARRETAS, Ma L. La encomienda, el priorato y la villa de Uclés en la Edad Media (1174-1310). Formación de un señorío de la Orden de Santiago. Madrid-Barcelona 1985. RodríGuEZ-PiCAVEA MATILLA, E. La formación del feudalismo en la meseta meridional castellana. Los señorios de la Orden de Calatrava en los siglos XII-XIII. Madrid 1994. Guerrero VenTAS, P. El Gran Priorato de Castilla y León de la Orden de San Juan de Jerusalén en el Campo de la Mancha. Toledo 1969, y la tesis más reciente de C. BARQUERO GoÑIZ, sobre la Orden de San Juan, sólo disponible en internet en la página del Departamento de Historia Medieval de la Universidad Autónoma de Madrid.

7 Hemos manejado la ed. de SÁNCHEZ BELDA, L. Chronica Adefonsi Imperatoris. Edición y estudio. Madrid 1950.

8 FERnÁNDez VAlverde, J. ed. de la Historia de rebus Hispanie sive Historia Gotbica de Don Rodrigo Jiménez de Rada en el Corpus Christianorum Continuatio Mediaevalis, por la ed. Brepols, Turnhout, $\mathrm{n}^{\circ} 72,1987$ disponible en $C$-D Ron. También ha publicado la traducción al castellano en

Hispania, LXII/1, núm. 210 (2002) 9-40 
especialmente para el reinado de Alfonso VIII y la noticia de la batalla de las Navas, de la que fue testigo directo. También hemos consultado otras crónicas, como la Crónica Latina de los Reyes de Castilla y la Primera Crónica General de Alfonso X el Sabio ${ }^{10}$, aunque su lectura ha sido bastante menos fructífera para nuestro propósito. Por otra parte, hemos estudiado otras obras de carácter regional, como los Anales Toledanos I y $I I^{11}$, un texto romanceado del siglo XIII que registra acontecimientos relacionados con la historia de la ciudad de Toledo y su tierra, y la Chronica de las tres Ordenes y cauallerias de Sanctiago, Calatrava y Alcantara $^{12}$, escrita por el Caballero Francisco de Rades y Andrada en el siglo XVI. Todas han tenido ediciones críticas excelentes más o menos recientemente, lo que facilita su estudio. En cuanto a la documentación de archivo, hemos consultado las bulas y diplomas de las Órdenes Militares procedentes de distintas colecciones. Para Calatrava hemos consultado la serie de Pergaminos ${ }^{13}$ y Libros de Registros de Escrituras de la Orden de Calatrava ${ }^{14}$, conservados en el Archivo Histórico Nacional de Madrid, además del Bulario de dicha Orden publicado en el siglo XVIII ${ }^{15}$. Para la Orden de Santiago interesan los documentos del Tumbo Menor de Castilla ${ }^{16}$ del mismo archivo, y también su Bulario ${ }^{17}$. Finalmente, para San Juan contamos con el reciente hallazgo del Libro de Privilegios de dicha Orden, publicado por el equipo del Prof. Ayala ${ }^{18}$. En total se han conservado alrededor de 900 diplomas fechados con anterioridad a 1250 que se reparten de la siguiente manera: Calatrava 230 documentos, Santiago 360 y San Juan 308 .

Fernández Valverde, J trad. de la Historia de los hechos de España de Don Rodrigo Jiménez de Rada. Madrid 1989.

9 Cabanes Pecourt, M.D. Crónica latina de los Reyes de Castilla. Valencia 1964. Más reciente, Charlo Brea, L. Crónica latina de los reyes de Castilla. Edición crítica y traducción. Cádiz 1984.

${ }_{10}$ Primera Crónica General de España que mandó componer el Rey Alfonso el Sabio. Ed. de R. MENÉNDEZ PIDAL, 2 vols, Madrid 1955.

11 ANALeS Toledanos. vol. XXIII de la España Sagrada de FlóREZ, pp. 381-409. Una ed. más reciente, con comentarios, Porres MARTín-Cleto, J. Los Anales Toledanos I y II. Toledo 1993.

12 RADES Y ANDRADA, F. de Chronica de las tres Ordenes y Cauallerias de Sanctiago, Calatrava y Alcantara. Toledo 1572, ed. facsimilar con estudio introductorio de D. LoMAX, Barcelona, 1980.

${ }_{13}$ Hemos consultado Documentos reales, carpetas 417 a 426, Documentos eclesiásticos, carpetas 440 a 445, y Documentos particulares, carpetas 455 a 461.

${ }_{14}^{14}$ Libros $n^{\circ} 1.341-c, 1.341-c$ bis, $1.342-c$ y $1.343-c$.

is OrTega y Cotes, I.J. Alvarez De Baquedano, J.F y OrTega ZúNiga y ARANDA, P. De $B u-$ llarium Ordinis Militiae de Calatrava. Madrid 1761. Reed. Facsimilar de LOMAX, D. En Barcelona 1981.

${ }_{16} \mathrm{Gran}$ parte de estos documentos pueden consultarse en la edición moderna que se contiene en los apéndices de las obras de D. Lomax, J.L. Martín y M. Rivera Garretas, ya citadas.

17 Aguado de Cordova, A.F., Aleman y Rosales, A.A. y Lopez Agurleta, J. Bullarium Equestris Ordinis S. Iacobi de Spata. Madrid 1719.

18 Ayala Martínez, C. de comp. y Barquero, C. Caunedo, B. García Turza, F.J., Matellanes, J. NovoA, F. Rodríguez-Picavea, E. Villalba, F.J. Libro de Privilegios de la Orden de San Juan de Jerusalén en Castilla y León (Siglos XII-XV). Ms. H211 del Museum and Library of the Order of St. John, de Londres. Madrid 1995.

Hispania, LXII/1, núm. 210 (2002) 9-40 
Nuestro trabajo se estructura en tres partes. La primera la denominamos De Toledo a Calatrava, pues se inicia con la toma de Toledo por Alfonso VI el año 1085 y concluye con la entrada de Alfonso VII en la ciudadela de Calatrava, situada ya en el valle del Guadiana, el año 1147. Las operaciones llevadas a cabo por las milicias castellanas contra los almorávides ${ }^{19}$ en el valle del Tajo y en la zona de los Montes de Toledo durante estos cincuenta años largos, son presentadas como el antecedente de la ocupación de la Mancha; aunque sin duda alguna la conquista de Toledo debe ser considerada un acontecimiento capital en sí mismo, dada la enorme importancia política y simbólica que tuvo en la época ${ }^{20}$. En segundo lugar nos ocupamos de la repoblación en la frontera toledana ${ }^{21}$ durante la segunda mitad del siglo XII, la fundación de las Órdenes Militares españolas de Calatrava y Santiago y la creación de sus dominios en tierras de la Mancha ${ }^{22}$, junto con el asentamiento de la Orden del Hospital en Consuegra ${ }^{23}$. El avance de la repoblación en este período fue inseguro, por lo que, cuando se produjo la reacción almohade a fines de dicha centuria, hubo una regresión consecuente a la derrota de Alarcos el año $1195^{24}$, hasta que la victoria de Alfonso VIII en la batalla de las Navas de Tolosa el año $1212^{25}$ permitió avanzar de forma segura y definitiva hasta los confines de los Campos de Calatrava y Montiel con las sierras béticas.

La fundación de las Órdenes Militares fue un fenómeno singular de los reinos cristianos del Occidente medieval que debe ser analizado en el doble

19 LAGARDÈRE, V. Les almoravides. Le djihâd andalou (1106-1143) París 1998.

20 Sobre la conquista de Toledo vid. R. IzQUIERDO BENITO coord. Alfonso VI y la toma de Toledo. Toledo 1986. También Estudios sobre Alfonso VI y la Reconquista de Toledo. Actas del II Congreso Internacional de estudios Mozárabes. Toledo 1987

${ }^{21}$ IZQUIERDO BENITO, R. Reconquista y repoblación de la tierra toledana. Toledo 1983.

${ }^{22}$ Una breve síntesis de la cuestión en AyAl.A MARTíneZ, C. de «Las Órdenes Militares y la ocupación del territorio manchego (siglos XII-XIII) en R. IZQUIERDO BENITO y F. RUIZ GómEZ coord. Alarcos 1195. Actas del Congreso internacional conmemorativo del VIII centenario de la batalla de Alarcos. Cuenca 1996, pp. 47-104.

23 Vid. Barquero GoÑI, C. «La Orden del Hospital en la Mancha durante los siglos XII y XIII" en Alarcos 1195 ... op. cit. pp. 289-314 y MOlero GARCíA, J.M. «Participación de la Orden del Hospital en el avance de la frontera castellana (1144-1224)» Ibid. pp. 331-353.

24 Además del estudio clásico de HUICI MIRANDA, A. Las Grandes batallas de la Reconquista durante las invasiones africanas (Almorávides, Almohades y Benimerines). Madrid 1956. Puede verse nuestro trabajo F. RUIZ GÓMEZ «La guerra y los pactos. A propósito de la batalla de Alarcos» en Alarcos 1195 ... op. cit. pp. 145-168.

25 Vid. Alvira Cabrer, M. «La muerte del enemigo en el pleno medievo: cifras e ideología (El modelo de Las Navas de Tolosa)» en Hispania LV/2 n 190 (1995) pp. 403-423, Id. «De Alarcos a las Navas de Tolosa: Idea y realidad de los orígenes de la batalla de 1212» en Alarcos 1195... op. cit. pp. 249-264.

Hispania, LXII/1, núm. 210 (2002) 9-40 
contexto de la Iglesia militante de la época de las Cruzadas y de la expansión europea en los siglos XI-XIII, protagonizada en su frontera oriental por los pueblos alemanes, y en la occidental por los reinos hispanocristianos ${ }^{26}$.

La ideología de estos caballeros y su relación con la mentalidad de cruzada ha sido estudiada minuciosamente por distintos especialistas hasta este momento ${ }^{27}$. Por nuestra parte, vamos a limitarnos a ofrecer una síntesis de esta cuestión apoyándonos exclusivamente en las fuentes de la época. Sin duda la referencia más conocida es el tratado doctrinal de San Bernardo titulado Alabanza de la nueva milicia, en favor de los caballeros del Temple ${ }^{28}$. Se inicia dicho escrito con la noticia de Novum militiae genus ortum... quam filios diffidentiae, in manu fortium, suorum dissipatos exterminet... et qua gemino pariter conflictu atque infatigabiliter decertatur, tum adversus carnem et sanguinem, tum contra spiritualia nequitiae in caelestibus... ${ }^{29}$. Pero la guerra, se nos advierte, es una actividad que discurre por el umbral impreciso del pecado. Para su prevención, la nueva milicia debe estar guiada por el amor a Cristo, sólo así resulta legítimo el empleo de la violencia para conseguir sus fines:

Non quidem vel pagani necandi essent, si quo modo aliter possent a nimia infestatione seu oppressione fidelium cohiberi. Nunc autem melium est ut occidantur...30.

Palabras duras. Más aún si pensamos en la rudeza y la crueldad de aquellos caballeros. Él propio Bernardo reconoce que muchos caballeros templarios habían sido, hasta no hacía mucho tiempo, sceleratos et impios, raptores et sacrilegos, homicidas, periuros atque adulteros... ${ }^{31}$. Ahora su lucha es sagrada, pero sus modales no habían cambiado mucho. San Bernardo lo censura y advierte que el caballero de Cristo debe ser el contrapunto de la milicia del mundo. Debe actuar con disciplina, aspirar a la perfección evangélica y renunciar a la riqueza personal. Todo lo demás es superfluo. Estos caballeros se tonsuran como los monjes, y no se dejan el pelo largo como hacen los otros que parecen mujerzuelas, rara vez se bañan y normalmente van cubiertos por el polvo y negros por el sol y la

\footnotetext{
${ }^{26}$ FOREY, A. The Military Orders. From the Twelfth to the early Fourteenth centuries. Toronto 1992.

27 Una revisión reciente de esta cuestión puede verse en GARCíA-GujJarro, L. Papado, Cruzadas y Órdenes Militares, siglos XI-XIII Madrid 1995.

${ }^{28}$ La edición de dicha obra puede consultarse en San BERNARDO. Obras completas. Edición bilingüe preparada por los monjes cistercienses de España. Biblioteca de Autores Cristianos. $\mathrm{N}^{\circ} 444$, Madrid 1983, pp. 494-543. Vid. también FLECKENSTEIN, J. «Die Rechtfertigung der geistlichen Ritterorden nach der Schrift De laude novae militiae Bernhards von Clairvaux» en FLECKENSTEIN, J y HofFMANN, M. eds. Die geistlichen Ritterorden Europas, Sigmaringen: Thorbecke, 1980, pp. 9-22.

29 «ba nacido una nueva milicia... que aspira a exterminar a los bijos de la infidelidad... y lucha sin descanso a la vez en un doble frente: contra los hombres de carne y bueso y contra las fuerzas espirituales del mal...»

30 «No es que necesariamente debamos matar a los paganos si bay otros medios para detener sus ofensivas y reprimir su violenta opresión sobre los fieles -cristianos-. Pero en las actuales circunstancias es preferible su muerte...»

31 «malvados e impíos, ladrones, sacrílegos, homicidas, perjuros y adúlteros...»

Hispania, LXII/1, núm. 210 (2002) 9-40
} 
herrumbre de la cota de malla. No atacan en tropel, sino ordenadamente, y no tienen miedo aunque estén en inferioridad numérica, porque tienen depositada su confianza en Dios. Y concluye este párrafo con una de las frases más célebres del tratado:

...pene dubitem quid potius censeam appellandos, monachos videlicet an milites, nisi quod utrumque forsam congruentius nominarim, quibus neutrum deesse cognoscitur, nec monachi mansuetudo, nec milites fortitudo 32.

Las Ordenes Militares españolas adoptaron este ideal de monachos videlicet an milites y lo reflejaron en sus estatutos y definiciones. En 1175, el Papa Alejandro III dictó una bula por la que ratificaba la fundación de la Orden de Santiago y solicitaba ayuda en favor de los freiles con palabras y argumentos muy parecidos a los de San Bernardo:

Versus Hispaniam contra gentem nefariam paganorum surrexerunt de novo viri Domini timentes et zelantes legem Domini, videlicet fratres Sancti Iacobi qui pro defensione fidei christiane se ipsos extremis periculis exponunt et finis christianitatis ab incursibus paganorum, induti lorica fidei et multiplici succincta virtute tuentur 33

La primera regla de la Orden de Calatrava, aprobada por el Capítulo General Cisterciense en 1164 expone su voluntad de Laudabile propositum vestrum, quo a militia mundi ad Dei militiam conversi, inimicos fidei expugnare statuistis... ${ }^{34} \mathrm{Y}$ el rey Alfonso VIII, en otro privilegio, expresaba con las siguientes palabras su deseo de proteger a los caballeros de Cristo Regali namque convenit maiestati quosque bonestos ac Religiosos viros diligere et eos maxime qui relictis saecularibus voverunt sponte contra Crucis Christi adversarios et propriam sanguinem fundere, seseque pro Christianis fidei defensione murum et clipeum constanter opponere ${ }^{35}$

Uno de los problemas principales con respecto a este movimiento fue la justificación de la violencia y los modales un tanto bruscos y mundanos de los

32 «Yo no sé cómo babría que llamarles, si monjes o soldados. Creo que para hablar con propiedad, sería mejor decir que son las dos cosas, porque saben compaginar la mansedumbre del monje con la fortaleza del soldado».

33 «En Hispania, contra la gente nefasta de los paganos, se levantaron de nuevo unos varones que temen a Dios y guardan con celo la Ley Divina; esto es, los bermanos de Santiago, quienes en la defensa de la fe cristiana ellos mismos se exponen a grandes peligros y protegen las fronteras de la cristiandad de las incursiones de los paganos, vestidos con la loriga de la fe y multiplicados sólo por la virtud». Doc. publicado por MARTín, J.L. op. cit. pp. 255 y ss.

${ }^{34}$ «...luchar contra los enemigos de la fe, convertidos de Milicia del. Mundo en Milicia de Dios.» Calatrava Bullarium, doc. de fecha 1164 , septiembre 14.

35 «los caballeros bonestos y religiosos y máxime a aquellos que dejadas la glorias seculares, bicieron votos espontáneamente de luchar contra los enemigos de la cruz de Cristo y derramar su propia sangre, y oponer sus propios cuerpos constantemente como muro y roca para la defensa de la fe cristiana.. AHN, Calatrava Lib. $1.341 \mathrm{c}$ bis. fol 22. 
caballeros de Cristo. Es sabido que la cuestión fue objeto de un vivo debate en la época, en el que participaron Hugo de San Víctor, contrario al uso de la violencia para la defensa de la fe ${ }^{36}$, y el propio San Bernardo quien, como ardiente partidario, compara a los caballeros del Temple con el mismo Jesucristo, ya que como ellos luchó y se inmoló a sí mismo por la salvación de toda la cristiandad. Cabe recordar que la parte segunda de la Alabanza de la nueva milicia contiene una descripción imaginaria de la geografía sagrada de Palestina para uso de peregrinos. El recorrido propuesto concluye con una visita a Betania, la patria de Lázaro, el vencedor de la muerte por voluntad de Jesucristo, y la Casa de la obediencia en donde vivieron sus hermanas Marta y María, y con las que Cristo platicó sobre los dos géneros de vida representados por cada una de ellas, la impetuosidad y el recato respectivamente. Esta imagen tuvo una cierta popularidad intelectual en la época. Sin duda fue del agrado de los monjes cistercienses, quienes la recordaron cuando el abad Raimundo de Fitero pidió al Capítulo General de dicha Orden que aceptara a los caballeros calatravos como vere fratres. En el Bulario de Calatrava se ha conservado un texto que recoge el mismo símbolo evangélico de Marta, a quien se identifica con la diligencia y la solicitud, y María que se relaciona con la paz y la oración. En cualquier caso, se afirma, ambas son dos formas igualmente virtuosas de servir a Dios:

«Per Marthae solicitudinem providendum esse Mariae quieti, ut orantis Mariae suffragiis, satagentis Marthae solicitudo ministerii juvaretur...»37.

Este discurso, propio de una Iglesia militante, fue bien recibido en la Península; aunque colisionara con algunas prácticas políticas de los reinos hispanocristianos, proclives a la negociación y al entendimiento con los musulmanes. Algo parecido ocurrió también en Palestina y otras zonas de contacto entre el Islam y la cristiandad. Como es bien sabido para el caso peninsular, la frontera no era una línea divisoria sino un espacio abierto en el que coexistían musulmanes y cristianos, caballeros y pastores, y en donde además de guerra y confrontación, había intercambios y una cultura generalizada del pacto ${ }^{38}$. Hay que recordar que la tradición del amān islámico fue aceptada y respetada también por los hispanocristianos y que las principales conquistas fueron el resultado de acuerdos políticos, como es el caso de Toledo. Don Rodrigo Jiménez de Rada nos da una versión de este acontecimiento, en donde se perciben las intrigas y negociaciones que precedieron a la capitulación de la ciudad:

\footnotetext{
36 Vid. comentario de LECLERCQ, E. «Un document sur les débuts des Templiers» en Revue d'bistoire ecclésiastique LII (1957).

37 "Por la diligencia de Marta se hace posible la paz de María, para que a los sufragios de los que oran a María, preocupados, se una la solicitud del ministerio de Marta» Calatrava Bullarium..., p.53.

38 Vid nuestro trabajo «La Guerra y los Pactos. A propósito de la batalla de Alarcos» en IZQUierdo Benito, R. y Ruiz Gómez, F. coords. Alarcos 1195. Cuenca 1996, pp. 145-168.
} 
Toletani... regi Aldefonso nuncios destinarunt... et ei per nuncios supplicarunt ut civitatem, quamvis inexpugnabilem, obsideret, ut coacti pugna colorem excusationis haberent, cum ei traderunt civitatem... et rex Aldefonsus id ipsum percipiens, congregato exercitu infinito obsedit secura suum Castella Toletum... Cepit itaque Toletum era MCXXIII multis pactionibus interpositis, uidelicet, ut Sarraceni haberent plene et integre domos et possessiones et omnia que habebant ${ }^{39}$

Los reyes, obispos, grandes magnates y concejos, todos tenían sus propias milicias y organizaban de forma periódica incursiones de saqueo en busca de botín, casi como una actividad económica. Como dice el autor de la crónica de Alfonso VII el emperador:

Consuetudo semper fuit Christianorum, qui habitabant trans Serram et in tota Extrematura, sepe per singulos annos congregare se in cuneos... et ibant in terram Moabitarum et Agarenorum et faciebant multas cedes et captiuabant multos Sarracenos et multam predam ${ }^{40}$.

A estas circunstancias históricas más o menos constantes habría que sumar otras coyunturales, como la ofensiva almohade, la separación de los reinos de León y Castilla después de 1157 y la larga minoridad del reinado de Alfonso VIII, hasta 1169, que crearon una nueva situación política y militar en la transierra. Ese fue el escenario en el que aparecieron las primeras Órdenes Militares españolas. En principio se trató de Hermandades de caballeros que, al igual que ocurría en algunos concejos de la frontera, tenían como objetivo simplemente la defensa de una ciudad en concreto. Dadas estas circunstancias no resultaba extraño que varias milicias concejiles se revistieran con un espíritu religioso y formaran Hermandades para articular la defensa conjunta de un territorio, como hicieron los fratres de Avila, o los freires de Cáceres, que constituyeron el germen de la futura Orden de Santiago. O como ocurrió con la Orden de Calatrava, cuyos documentos fundacionales aluden exclusivamente a la defensa de esta ciudad y su territorio. Por lo tanto, cabe afirmar que el comportamiento de las Órdenes Militares peninsulares, en principio, fue comparable al de las

39 «Los toledanos... enviaron mensajeros al rey Alfonso... y le imploraron que asediara la ciudad por muy inexpugnable que fuera, para que, forzados por el combate, pudieran guardar las apariencias cuando se la entregaran. Y Alfonso..., aceptada la oferta de los vecinos, reunió un ejército de todos los rincones de su reino y... así tomó Toledo en la era de 1123, fijándose muchas condiciones, a saber que los sarracenos conservarian de pleno derecho sus casas, tierras y todo lo que poseían...» Rodrigo Ximénez de Rada, Historia de rebus Hispaniae sive Historia Gothica, Lib. VI, cap. XXII ed. de FernándeZ VAlverde, J. en el Corpus Christianorum Continuatio Mediaevalis, Brepols, Turnhout, $\mathrm{n}^{\circ} 72,1987$ disponible en C-D Ron. Trad. del mismo autor Historia de los bechos de España de Don Rodrigo Jiménez de Rada. Madrid 1989.

40 "Fue siempre la costumbre de los cristianos que babitaban en la Transierra y en toda Extremadura, congregarse a menudo cada año en cuñas... e iban contra la tierra de los moabitas y los agarenos... y cautivaban a muchos sarracenos, y tomaban mucbo botín» Chronica Adefonsi Imperatoris, ed. Sánchez Belda, 1950, 88-89. 
milicias concejiles, y también al de ciertos señoríos independientes de la frontera, de los que hablaremos en otra ocasión.

Durante el período que va de la conquista de Toledo en 1085, hasta la toma de Calatrava en 1147 se produjo una contención, seguida de un retroceso de la frontera toledana como consecuencia de las campañas almorávides para someter a las taifas, cuyos hitos fueron Zalaca (1086) y Uclés (1108), así como el desarrollo de las alianzas políticas y militares, en la línea del vasallaje, a uno y otro lado de la frontera durante la crisis de Urraca y los primeros años del reinado de Alfonso VII. Superada esta situación hacia 1130, tuvieron lugar nuevos intentos de repoblación en torno a Toledo y otros puntos del valle del Tajo, y el inicio de la conquista de la cuenca del Guadiana seguida de la aparición de los primeros asentamientos hispano-cristianos en la zona.

La ciudad de Toledo fue la cabeza de un distrito fronterizo en época Omeya, denominado Marca Media, en donde dominaban ciertos clanes bereberes que mantuvieron una actitud de resistencia frente a Córdoba ${ }^{41}$. La falta de disciplina de las guarniciones militares de la zona y el predominio de las tendencias segmentarias en las tribus fue evidente tras la crisis del califato y determinó la evolución política de las primeras taifas. La dinastía dominante en Toledo, la de los Banū Dī l-Nūn ${ }^{42}$, trató de reforzar su posición manteniendo una dependencia tributaria y una relación de vasallaje con Alfonso VI, habitual en el régimen de parias, que concluyó con la entrega pactada de la ciudad en 1085, como ya se ha dicho. Tras la toma de Toledo se conquistó el valle del Tajo hasta los Montes de Toledo por el sur, a la altura de Consuegra y Mora. Por el norte las tierras ocupadas comprendían los valles del Jarama, Guadarrama y Alberche que llegaban hasta Talamanca, Madrid, Alcalá y Guadalajara, Por el oeste se extendían hasta Talavera, incluyendo Maqueda y Santa Ola$\mathrm{lla}^{43}$. Al este quedaban las tierras de Cuenca con Uclés, Alarcón, Huete y Santaver. El rey Alfonso renunció a ocupar estas tierras por las condiciones del pacto de capitulación suscrito con al-Qādir, a quien las cedió en reconocimiento del derecho tradicional de este linaje sobre dicho distrito ${ }^{44}$. Al sur de los Montes de Toledo se extendía el distrito de Calatrava que tampoco fue ocupado por los castellanos después de 1085. Alfonso VI era consciente de que no podría repoblar tan amplios territorios, más aún tras la ofensiva almorávide

\footnotetext{
41 Manzano Moreno, E. La frontera de al-Andalus en época de los Omeyas. Madrid 1991, pp. 259 y ss.

${ }_{42}$ Dunlop, D.M. "The Dhunnunids of Toledo» en Journal of the Royal Asiatic Society (1942) pp. 77-96. El mismo «Notes on the Dhunnunids of Toledo» en Journal of the Royal Asiatic Society (1943) pp. 17-19.

43 IZQUIERDO BENITO, R. Reconquista y repoblación de la tierra toledana. Toledo 1983. Id. Coord. Alfonso VI y la toma de Toledo. Toledo 1986.

${ }_{44}$ Además de los datos que proporciona la Crónica del Toledano, en especial en su Lib. VI, cap. XXII, vid. el minucioso análisis de la cuestión según las fuentes árabes en WASSERSTEIN, D. The Rise and Fall of the Party-Kings. Politics and society in Islamic Spain. 1002-1086. Princeton, 1985, p. 255.
}

Hispania, LXII/1, núm. 210 (2002) 9-40 
que obligó evacuar todas las posiciones en la línea de los Montes de Toledo. Por otra parte, Calatrava fue una taifa independiente durante un breve período de tiempo a la caída del califato, para pasar después a depender de la taifa de Sevilla ${ }^{45}$, por lo que también permaneció fuera de la influencia toledana.

Los almorávides mantuvieron la presión sobre Toledo en los primeros años del siglo XII y ocuparon las tierras circundantes y sus principales fortalezas después de la batalla de Uclés (1108), en donde murió el príncipe heredero Sancho, por lo que al descalabro militar se añadía una crisis política de consecuencias duraderas. Pero los almorávides se anexionaron también las taifas ${ }^{46}$, por lo que los caudillos andalusíes reanudaron los tratos con los castellanos cuando se produjo su decadencia, lo que permitió el avance de la frontera nuevamente al sur de los Montes de Toledo a partir de finales de la década de 1130/40. De forma que la crisis almorávide y la quiebra del régimen de parias hizo posible el asentamiento por la vía del pacto de las primeras posiciones cristianas al sur de los Montes de Toledo, en pleno Campo de Calatrava y en las llanuras de la Mancha.

La primera repoblación cristiana de este territorio se hizo sobre la base de los antiguos distritos (iqlīm) existentes en época islámica, modificados parcialmente por los acontecimientos de la conquista. Los sistemas de articulación del territorio toledano y las pautas del poblamiento al final del dominio islámico dejaron una profunda huella en la región, percibiéndose dos modelos complementarios uno urbano y otro rural. La ciudad (mädina) de Toledo era el centro de actuación del poder estatal, jerarquizador e integrador, que incluía también un territorio circundante, al-hawz, intensamente explotado, con huertas (almunya) y jardines de propiedad privada (bustān y rahal) ${ }^{47}$. En las zonas rurales más alejadas se mantenía la 'asabiyya tribal en las comunidades campesinas segmentarias las cuales, a falta de ciudades importantes, dependían de un castillo (bisn) ${ }^{48}$ como Calatrava, Uclés o Consuegra, a cuyo frente había un qāidd que era la representación del poder estatal, mientras que los grupos tribales residían en alquerías.

${ }^{45}$ Los datos al respecto que de forma difusa proporciona el Toledano son sintetizados y cotejados por J. GonZÁLEZ, 1975, op. cit. vol I, pp. 82 y 83.

46 VIgUera MOLINS, M.J Los reinos de taifas y las invasiones magrebies. Madrid 1992. También Viguera Molins, M.J. Coord ${ }^{a}$ y Prólogo, El retroceso territorial de al-Andalus. Almorávides y almobades. Siglos XI al XIII. Tomo VIII-II de la Historia de España, Ramón Menéndez Pidal. Ed. Espasa-Calpe, Madrid 1997.

47 Los modelos de poblamiento y articulación del espacio andalusíes han sido expuestos fundamentalmente por P. Guichard y A. Bazzana en diversas obras cuya referencia no viene al caso en este trabajo. Sobre las pautas del poblamiento en Toledo y su tierra vid. LAGARDÈre, V. Campagnes et paysans d'al-Andalus (VIII'-XV' siècles). Paris 1993, pp. 66-74.

48 MalPiCa COELlo, A. ed. Castillos y territorio en al-Andalus. Jornadas de Arqueología Medieval. Granada, 1998.

Hispania, LXII/1, núm. 210 (2002) 9-40 
Entre 1120 y 1140 hubo enfrentamientos y contactos frecuentes entre musulmanes y cristianos en tierras de la Mancha, por lo que surgió una cultura mixta en la que, junto a ideas radicales excluyentes como la Cruzada o el Yihād, proliferaron las relaciones de vasallaje y la prestación de servicios militares y mercenarios. Un caso bien conocido es el vasallaje de Zafadola a Alfonso VII y su asentamiento en la frontera, más concretamente en la tierra toledana, para hostigar a los almorávides ${ }^{49}$, hasta concluir en ruptura cuando el rey castellano vio la posibilidad de articular un sistema personal de alianzas con otros caudillos andalusíes, como Ibn Mardanīš. Del lado cristiano destacan ciertos linajes castellanos poderosos, como Castros y Laras, y sobre todo algunos linajes secundarios que ejercieron la alcaidía de los castillos fronterizos. Tal es el caso de Muño Alfonso, señor de Mora y alcaide de Toledo, que murió luchando contra los musulmanes en los pozos de Algodor en 1143, un claro representante de los caballeros llamados en la época viri bellicosi, cuyo estudio permitiría realizar aportaciones a una sociología de la guerra en la frontera.

La crisis final del Imperio almorávide aceleró el avance de la frontera hispano-cristiana, realizándose también incursiones en profundidad, como la que culminó con la conquista de Almería el año 1147. Los hitos más importantes en el marco regional de la Mancha fueron la reconstrucción de Aceca el año 1138 y la conquista del castillo de Oreja en $1139^{50}$, con lo que se recuperaba el dominio sobre la línea del Tajo. Después se avanzó hacia el sur de los Montes de Toledo, el año 1144 se conquistó el castillo de Mora y en 1147 consiguió entrar el emperador en Calatrava ${ }^{51}$, con lo que sus dominios llegaban por primera vez hasta las estribaciones de Sierra Morena. Estos triunfos permitieron desarrollar la primera repoblación de la zona con ciertas garantías de continuidad.

Hay indicios suficientes para afirmar que la repoblación de Toledo y la vega del Tajo se realizó, por primera vez, por medio de repartimientos ${ }^{52}$. Como es bien sabido, no se han conservado libros de rapartimientos para la zona de Toledo y los primeros conocidos se refieren a Valencia después de su conquista en 1238, pero el estudio de la serie de documentos denominada Fueros de Toledo $0^{53}$, así como las condiciones pactadas para la capitulación de la ciudad, permite

49 Vid. Chronica Adefonsi Imperatoris Lib. I caps. 27 y 29.

${ }^{50}$ Chronica Adefonsi Imperatoris Lib. II, Cap. 49.

s1 GONZÁlEZ opina que Calatrava fue entregada a los cristianos como consecuencia del vasallaje de Abengania, último gobernador almorávide de Córdoba enfrentado con los almohades por entonces. Op. cit. Tomo I, p. 148.

52 La idea la expuso ya GonZÁlez, J. al analizar la dotación de la Catedral de Toledo después de la conquista, op. cit. tomo I, pp. 113 y ss. GLICK, Th. C. da por supuesto que en el valle del Tajo no pudo haber presuras, por la intensidad de su poblamiento, y que hubo repartimientos que constituyeron el antecedente del de Valencia, Cristianos y musulmanes en la España medieval (711-1250) Madrid 1991, p. 90. MOLENAT insiste sobre esta cuestión, a pesar de la referencia a las presuras del privilegio de los mozárabes de 1101, 1996, op. cit. p. 78 y ss.

s3 Publicados por García Gallo, A. "Los fueros de Toledo» en Anuario de Historia del Derecho Español XLV (1975) pp. 341-488.

Hispania, LXII/1, núm. 210 (2002) 9-40 
afirmar que así fue ${ }^{54}$. La pervivencia de ciertos privilegios para la población mozárabe y mudéjar después de la conquista ${ }^{55}$, así como la extensión del derecho de los castellanos y de los francos nos confirma la existencia de una población heterogénea muy característica en esta zona, que tiende a difuminar sus diferencias entre sí a lo largo del siglo XIII; aunque la presencia e identidad de cada uno de los grupos perduró durante toda la edad media. En la ciudad de Toledo predominó el grupo aristocrático formado por caballeros castellanos ${ }^{56} \mathrm{y}$ mozárabes ${ }^{57} \mathrm{y}$, junto a ellos, la clerecía de la catedral, dirigida por los borgoñones cluniacenses y protegida por el entorno cortesano del monarca ${ }^{58}$.

Las tierras más alejadas se repoblaron según el modelo denominado de castrum et villa ${ }^{59}$; es decir, un sistema articulado en torno a un castillo y una villa o puebla a sus pies, como prueba evidente de la importancia de los castillos y las defensas en los asentamientos de la frontera. El modelo puede ilustrarse en Aceca ${ }^{60}$, en donde tenemos un castillo con su alcaide y un grupo de caballeros, acogidos al derecho de las cabalgadas, dominante sobre una villa, poblada por mozárabes y mudéjares que cultivan sus tierras circundantes, y del que dependen otras pequeñas aldeas próximas, normalmente sin defensas. De forma similar se conservaron otros antiguos distritos islámicos después de la conquista cristiana, como ocurrió en Calatrava, Consuegra y Uclés. La ocupación de estos lugares, futuro asiento de las principales Órdenes Militares, se hizo manteniendo prácticamente inalterables la organización territorial en torno a los busūn islámicos precedentes que fueron la base sobre la que se articuló la primera repoblación de las tierras situadas al sur de los Montes de Toledo.

Los límites del Campo de Calatrava son conocidos por un documento fechado en $1189,{ }^{61}$ en donde se describe el antiguo distrito islámico que se ex-

\footnotetext{
${ }^{54}$ GaRCía Gallo afirma que la corona realizó una distribución equitativa de bienes entre los conquistadores, por lo que debió realizarse una pesquisa, como se indica en el privilegio de los mozárabes de Toledo, op. cit. (1975) p. 423.

ss ReiLly, B.F. El reino de León y Castilla bajo el Rey Alfonso VI (1065-1109). Toledo 1989, p. 193.

${ }^{56}$ Los castellanos debieron recibir una carta de privilegios anterior a la de los mozárabes de 1101 cuyo contenido se conoce por el posterior fuero refundido de Toledo, ed. de García Gallo, doc. $\mathrm{n}^{\circ} 10$ «recopilación de los fueros de Toledo, atribuida a Alfonso VII en 1118 (hacia 1166)» op. cit. p. 473.

57 Carta de seguridad concedida a los mozárabes de Toledo por Alfonso VI (19 de marzo de 1101), ed. de García Gallo, 1975, op. cit. p. 459.

58 El privilegio del fuero eclesiástico de los clérigos de Toledo se aprobó en tiempos del primer arzobispo don Bernardo. El privilegio original no se ha conservado, pero su contenido se conoce por la confirmación hecha por Alfonso VII en 1136, publ. por GARCía GALLO, 1975, op. cit. p. 468.

$59 \mathrm{La}$ expresión la propone LALIENA CORBERA, C. en Sistema social, estructura agraria y organización del poder en el Bajo Aragón en la Edad Media (siglos XII-XV). Teruel 1987, pp. 28.

60 Vid. fuero de Aceca de 1102, el texto que publicó Menéndez Pidal en los Documentos lingüísticos, es a todas luces una copia posterior, fechada en 1235, con interpolaciones de cláusulas propias del siglo XIII. Nosotros manejamos la ed. de GARCía Gallo, 1975, op. cit. p. 463, y también la copia manuscrita en AHN, OOMM, Calatrava Lib. $1.341 \mathrm{c}$ bis fol $220 \mathrm{v}^{\circ}$.

${ }_{61}$ Bulario de Calatrava doc. de fecha 1189 , septiembre 22, pp. 26-28.
} 
tendía entre el Puerto del Muradal, en sierra Morena por el sur, y el de Orgaz, en los Montes de Toledo por el norte. Comprendía las tierras del valle del Guadiana hasta el límite con las extremeñas en la sierra de la Umbría. En el centro de este territorio se encuentra la ciudad de Calatrava (la Vieja) junto al Guadiana, de la que dependían otros castillos de la zona como Malagón, Alarcos, Piedrabuena, Caracuel, Salvatierra ya en el paso hacia el valle de Alcudia, y el castillo de Chillón al sur, cerrando dicho valle por el oeste. La villa y arce de Calatrava recibió fuero de manos de Alfonso VII tras su entrada el año $1147^{62}$. Se trata de un fuero de población de tradición mozárabe que podemos relacionar con el fuero de Oreja; por lo que se sitúa en la órbita de influencia de los fueros de los castellanos de Toledo. La mezquita de Calatrava fue consagrada como iglesia y se convirtió en un arcedianazgo dependiente del arzobispado de Toledo ${ }^{63}$. La defensa de la plaza fue encomendada a los templarios por poco tiempo, pues en 1157, renunciaron a ella ante la amenaza de una ofensiva almohade que nunca se produjo ${ }^{64}$. Al año siguiente el rey Sancho III de Castilla aceptó la propuesta cisterciense de crear una Orden Militar nueva, la Orden de Calatrava con el propósito de defender la plaza del mismo nombre y su Campo, con lo que se creaba la primera de las Órdenes Militares españolas.

La documentación calatrava de los primeros tiempos contiene algunas descripciones de los paisajes de la repoblación, en los que se refiere la existencia de parajes naturales de interés pastoril, como navas, valles y, sobre todo, nos parece significativa la mención de mestas, probablemente una de los registros más antiguos de este término que alude a lugares de reunión de pastores para dirimir conflictos sobre la propiedad de determinadas cabezas y el aprovechamiento de los pastos:

«...del encinar del Pedroch, et sicut vadit inferius circa Castellum Sanctae Eufemiae, et inde vadit ad Mestas recte ad locum, ubi intrat Rivus de Alcudia, et rivus de Gargantiel in Rivum de Guadarmes»65.

También se refleja en estos documentos la importancia de los castillos, situados junto a las dehesas, como los de Murgabal, Santa Eufemia o Chillón, los tres localizados en el límite del Campo de Calatrava por el sur. Hay un interés

\footnotetext{
${ }_{62}$ AHN, OOMM, Calatrava, Lib. Reg. Escritutras 1.341-c fol. 4. Hay una ed. reciente de este documento en Alvarado Planas, J. «Los fueros de concesión real en el espacio castellanomanchego (1065-1214): El Fuero de Toledo» en la obra coordinada por el mismo Espacios y fueros en Castilla-La Mancha (siglos XI-XV). Una perspectiva metodológica. Madrid 1995, pp. 138-139. Otra más reciente, con algunas variantes, se debe a RoDríGuez-PICAVEA MATILlA, E. «Calatrava. Una villa en la frontera castellano-andalusí del siglo XII» en Anuario de Estudios Medievales 30/2 (2000) pp. 807-849.

63 Vid. doc. de fecha 1147, enero, inserto por RADES, en su Chronica de Calatrava, op. cit. p. 3.

${ }^{64}$ Ibid. p. 4, vid. nuestro comentario en «Las Ordenes Militares y la Reconquista Española del siglo XII: La Orden de Calatrava.» En ZOZAYA, J. ed. Alarcos'95. El fiel de la Balanza. 1995 pp. 113-129.

65 Ibid. doc. de 1189 , citado en nota 61.
} 
evidente por consignar las principales zonas de pasto y los puntos de paso de recuas y ganados, como el puerto de Alhobet, hoy conocido como puerto del Milagro, y el puerto de Orgaz junto a la villa toledana del mismo nombre, que hoy se conococe como Puerto de los Yébenes. Con todas estas referencias es posible trazar con precisión el límite del Campo de Calatrava a mediados del siglo XII que venía a coincidir por el sur, el oeste y el norte con los límites actuales de la provincia de Ciudad Real. No conocemos en cambio sus límites por el este, donde se encontraba la amplia llanura de la Mancha que por entonces ocupaban los distritos de otros castillos como Uclés, Consuegra y Alhambra.

El distrito de Uclés se extendía originariamente desde el Tajo hacia el sur, por las tierras comprendidas entre los ríos Riánsares y Cigüela tributarios del Guadiana. Por lo tanto se distribuía a modo de gran corredor en sentido longitudinal norte-sur siguiendo las vías naturales de desplazamiento de los rebaños en busca de los pastos de invierno. Los centros del distrito eran, naturalmente, Uclés y Tarancón. En la línea del Tajo disponía de algunos castillos que aseguraban el control de los vados, como eran Alboer (hoy Villamanrique de Tajo). La mayor concentración de aldeas se daba en torno a Uclés, en las estribaciones de la sierra. Más al sur disminuía la intensidad del poblamiento, extendiéndose el distrito por la llanura de la Mancha hasta contactar con el de Consuegra a la altura de Almaguer ${ }^{66}$. La villa de Uclés y su tierra fue entregada por Ibn Mardanis a Alfonso VII hacia 1157 a cambio del castillo de Alicún ${ }^{67}$. Tras diversos cambios de titularidad, el lugar fue entregado a la Orden de Santiago en $1174^{68}$, que consolidó y amplió su dominio considerablemente tras la conquista castellana de Cuenca en 1177. El año 1179, el maestre don Pedro Fernández concedió fuero latino a la villa de Uclés para su repoblación ${ }^{69}$. Se trata de un fuero de tradición castellana que constituye el antecedente del fuero de Cuenca. La villa contaba por entonces con seis collaciones, dos arrabales y un amplio término con 25 aldeas, repartidas en 3 sexmerías.

El castillo de Consuegra constituía una posición importante en las estribaciones orientales de los Montes de Toledo al sur de Mora, desde donde dominaba la amplia llanura de la Mancha por el alto valle del Guadiana hasta Ruidera. Fue conquistado por Alfonso VI junto con la ciudad de Toledo en 1085, y perdido posteriormente en $1099^{70}$. Su recuperación debió producirse entre

${ }^{66}$ Vid. Bula de Lucio III de 1184, noviembre 17. Verona. Por la que se confirma la fundación de la Orden de Santiago. Publ. por J.L. MARTín, op. cit. pp. 350-351. P. 198.

67 Recuero Astray, M. Alfonso VII el emperador. El Imperio Hispánico en el siglo XII. León 1979.

68 doc. de 1174, enero 9, por el que Alfonso VIII hace donación de la villa castillo y tierra de Uclés a la Orden de Santiago, incluido en el Bullarium de Santiago pp. 11-12.

69 Rivera Garretas, M. »el fuero de Uclés (siglos XII-XIV)» en Anuario de Historia del Derecho Español LII (1982) pp. 243-348. La misma, La encomienda, el priorato y la villa de Uclés en la Edad Media (1174-1310). Formación de un señorio de la Orden de Santiago. Madrid-Barcelona 1985.

70 Anales Toledanos I, p. 69 de la ed. citada. 
1144 (fecha de la conquista de Mora) y 1147 (entrega de Calatrava), aunque es posible que estuviera despoblado por entonces. El año 1151 fue entregado por Alfonso VII al caballero Rodrigo Rodríguez ${ }^{71}$. Por dicho documento conocemos con detalle los límites de su distrito que se extiende desde los confines con Mora, en los Montes de Toledo, hasta los de Uclés, por el norte. Al oeste el límite lo traza la vía que va de Toledo a Calatrava, a la altura de la sierra de la Calderina, hasta llegar al Guadiana por el sur. Por el este comprende la llanura manchega entre el Záncara y el Cigüela, que por entonces se encontraba prácticamente despoblada hasta Criptana. Finalmente el castillo de Consuegra fue entregado por Alfonso VIII a la Orden de San Juan, en 1183, agosto $6^{72}$, convirtiéndose en cabecera de encomienda y futura sede del Priorato de esta Orden en la Mancha.

La segunda mitad del siglo XII fue una época de recuperación del poder político de la monarquía castellana y en ella se produjo también la fundación de las Órdenes Militares españolas. Se trata de una tendencia amplia que se caracterizó, entre otras cosas, por la expansión cisterciense ${ }^{73}$, lo que evidentemente tuvo una relación directa con la fundación de Calatrava ${ }^{74}$. Por otra parte, la frontera permaneció estable durante las segundas taifas que se sucedieron tras la caída del imperio almorávide (1140-1160) y después por las limitaciones del poder almohade en al-Andalus. De hecho las primeras incursiones almohades contra la tierra de Toledo (asedio de la ciudad en 1171 y campaña de Huete en 1172$)^{75}$ no se produjeron hasta la caída del régimen mardanisí y concluyeron con un relativo fracaso. Por el contrario, poco después tuvo lugar un importante avance castellano por el alto Júcar, con la toma de Cuenca (1177) y Alarcón (1184). Los almohades trataban de compensar la debilidad de su intervención con una política de alianzas y treguas pactadas que contrarrestaba las fuerzas de los reinos hispano-cristianos. Es conocida la dependencia vasallática de los reinos de León y Navarra con los almohades a fines del siglo XII. Pero esto no impidió el desarrollo de la repoblación en las tierras de la frontera castellana en la época de la fundación de las Órdenes Militares.

${ }^{71}$ Doc. publicado con el $n^{\circ} 64$ en el Libro de Privilegios de San Juan, ed. de C. de AYALA et alii, op. cit. corrige la fecha del mismo en 1151.

72 Libro de Privilegios de San Juan..., 1995 op. cit. doc. $\mathrm{n}^{\circ} 144$. la 1981

73 PORTEla Silva, E. La colonización cisterciense en Galicia (1142-1250), Santiago de Composte-

74. O'CALlaghan, J. «The Affiliation of the Order Calatrava with the Order of Citeaux» incluido en The Spanish Military Order of Calatrava and its Affiliates, London, Variorum Reprints, 1975.

75 Vid. nuestro comentario de esta campaña en «La guerra y los pactos. A propósito de la batalla de Alarcos» en Alarcos $1195 \ldots$ op. cit. pp. 145-168.

Hispania, LXII/1, núm. 210 (2002) 9-40 
A mediados del siglo XII la corona trataba de reforzar su poder en la extremadura castellana. Los obispos, cluniacenses en su mayoría, y la alta nobleza (Castros, Laras, López de Haro) representaban un peligro para ello, sobre todo en momentos de debilidad como las minorías de edad de los reyes. Los caballeros de la frontera, esos viri bellicosi a los que nos hemos referido anteriormente, eran indisciplinados. Se hizo patente por entonces la necesidad de imponer una dirección política a la guerra en la frontera que obedeciera a estrategias amplias de ocupación del espacio trazadas por la monarquía. En consecuencia, los caudillos de la frontera tuvieron que aceptar una disciplina más estricta en sus actuaciones, como muestran las disposiciones al respecto de fueros como el de Cuenca ${ }^{76}$. Las milicias de los concejos de la transierra castellana cobraron importancia en esta época y el rey impulsó su desarrollo junto con el de otros señoríos de frontera, también de tradición islámica, como los de Molina y Albarracín, que gozaron de gran autonomía. Por otra parte, continúan registrándose donaciones a favor de pequeños caballeros de la frontera como Rodrigo Muñiz, señor de Mora ${ }^{77}$, Rodrigo Rodríguez en Consuegra ${ }^{78}$, o Tello Pérez, encargado de la repoblación en el valle del Guadiana ${ }^{79}$. El estudio prosopográfico de este grupo nobiliario de segundo orden indica que, en su mayor parte, estuvieron relacionados con la fundación de las Órdenes Militares, como también lo estuvieron los grandes señores y las milicias concejiles. La corona optó finalmente por la creación de las Órdenes Militares como institutos poderosos y fieles capaces de dominar en varios castillos a un mismo tiempo sobre territorios más extensos. A partir de entonces muchos caballeros de la segunda generación en la transierra ingresaron en las Órdenes, otros simplemente se situaron en su órbita y mantuvieron una relación de familiaridad. Es probable que la intervención de la corona en la repoblación a través de caballeros del entorno cortesano, y la fundación de las Órdenes Militares sean dos aspectos de una misma política a fines del XII. Así se percibe al menos en algunos procesos fundacionales.

La fundación de la Orden de Calatrava tuvo lugar el año $1158^{80}$ y fue la primera de las Órdenes Militares españolas. En 1164 fue aprobada su primera

76 Vid. nuestro trabajo «La Hueste de las Órdenes Militares» en Las Órdenes Militares en la Península Ibérica. Volumen I: Edad Media. Ricardo Izquierdo Benito y Francisco Ruiz Gómez Coords. Cuenca 2000, pp. 403- 436

77 Vid. doc. de 1150, publ. por MarTín, 1974, op. cit. apéndice doc. ${ }^{\circ} 14$.

78 Ibid. doc. citado en nota $n^{\circ} 71$.

79 En 1173, Alfonso VIII hizo donación de la villa de Ocaña a Pedro Gutiérrez y a Tello Pérez, probablemente hermanos. En los próximos años ambos hicieron donación de sus villas de Aceca y Ocaña a la Orden de Calatrava. Finalmente en 1181 el Maestre de Calatrava encomendó al caballero Tello Pérez la repoblación del valle del Guadiana, Bulario de Calatrava, doc. de fecha 1181, enero 3 p. 16.

${ }^{80}$ La noticia se contiene en JIMÉNEZ DE RADA, Lib. VII, Cap. 14, también en RADES, Chronica... op. cit. p. $4 \mathrm{r}^{\circ}$ y $4 \mathrm{v}^{\circ}$. Se ha conservado el documento por el cual Sancho III de Castilla concede a Raimundo de Fitero la plaza de Calatrava en 1158, en Bulario de Calatrava p. 2. y AHN Calatrava Lib. $1.341 \mathrm{c}$ bis fol 1.

Hispania, LXII/1, núm. 210 (2002) 9-40 
regla y forma de vida por el Capítulo General Cisterciense ${ }^{81}$ y el papa Alejandro III ratificó su existencia con una bula confirmatoria ese mismo año ${ }^{82}$. La Orden estaba dirigida por un Maestre, un Prior y un Capítulo General y contaba con freiles caballeros y conventuales o clérigos. Pronto surgió el enfrentamiento entre ambos grupos, como sucedió en otros institutos similares, lo que se resolvió a favor de los caballeros con la elección del primer Maestre don Martín. Sin embargo se impuso una dependencia canónica de la Orden Cisterciense. El abad de Morimond tuvo derecho de visita y corrección espiritual, que normalmente delegó en el abad de Gumiel de Hizán, fundación calatrava en tierras burgalesas en donde se refugiaron los conventuales tras la primera crisis. ${ }^{83}$ También hubo conflictos con la mitra toledana en relación con la fundación y administración de las parroquias de los lugares calatravos. Para su resolución, se alcanzó una concordia, como refleja la segunda bula confirmatoria de la Orden de $1187^{84}$, por la que se ratificó el privilegio de exención cisterciense sobre fundación de iglesias y provisión de curatos, aunque se aprobó también el derecho diocesano de presentación de clérigos y el de percepción de la tercia pontifical de los diezmos novales. El patrimonio calatravo era muy extenso y por entonces se asentaba preferentemente en el Campo de Calatrava, comprendiendo una superficie de $13.432 \mathrm{~km}^{2}$ En este territorio poseía a fines del XII más de diez castillos y cinco encomiendas, además contaba con importantes posesiones en Toledo y la vega del Tajo, muy rentables, y otros muchos lugares dispersos por distintas regiones peninsulares al norte del Sistema Central ${ }^{85}$. Fuera del reino de Castilla, la Orden contó con otros institutos filiales como la Encomienda Mayor de Alcañiz, en Aragón, la Orden de San Julián del Pereiro o de Alcántara en León, y la Orden de Évora o de Avís en Portugal. Además recibió importantes privilegios reales sobre organización de cabalgadas, derechos sobre el quinto del botín y recaudación de portazgos de recuas y ganados $^{86}$. A los veinte años de su fundación, la Orden de Calatrava constituía un instituto religioso muy poderoso sobre el que la corona castellana ejerció una influencia muy directa.

La capacidad militar de la Orden y las posibilidades de acometer la repoblación de un territorio tan extenso como el Campo de Calatrava eran no obstante limitadas. Calculo que los castillos de la Orden disponían, en líneas gene-

81 Bulario de Calatrava p. 3.

82 Bulario de Calatrava, p. 5

83 RADES Y ANDRADA, Chronica de Calatrava, op. cit. p. $10 \mathrm{v}^{\circ}$ y $11 \mathrm{r}^{\circ}$.

84 Publ. Calatrava Bulario pp. 22-25.

85 Presento por el momento una síntesis a partir del cotejo de toda la serie documental de la Orden de Calatrava desde su fundación hasta finales del siglo XII y, en especial del punto tercero de la segunda bula confirmatoria de la Orden promulgada por Gregorio VIII en 1187, lo que espero ofrecer pronto de forma más detallada en un estudio más extenso.

86 Bulario de Calatrava, doc. de fecha 1173 , junio 28 , p. 8. También, doc. de fecha 1175 , marzo 8, publ. Bulario de Calatrava p. 11.

Hispania, LXII/1, núm. 210 (2002) 9-40 
rales, de una guarnición de unos 10 caballeros, mantenidos por la explotación de sus dehesas circundantes y el cultivo de unas 40 yugadas $(1.000 / 1.200 \mathrm{Has})$ de heredad ${ }^{87}$. Pero estos castillos no sólo eran insuficientes para dicho territorio, además muchos eran muy pequeños o estaban en ruinas por ser construcciones en tapial. Fue frecuente que la Orden tuviera un señorío compartido sobre dichos castillos con la corona y los grandes linajes, como el de los Lara, como ocurrió en el castrum de Chillón que tenía aneja la explotación de la mina de Almadén ${ }^{88}$. En otras ocasiones la Orden concedió prestimonios a caballeros de la frontera para la reconstrucción de castillos y la repoblación de sus tierras circundantes, como hizo en 1181 con el caballero Tello Pérez, a quien encomendó la repoblación de 30 yugadas de heredad junto a algunos castillos del Guadiana ${ }^{89}$. Las concesiones de prestimonios sobre castillos por parte de la Orden en favor de caballeros de la frontera se hicieron habituales y fue una de las vías para el engrandecimiento del dominio calatravo por entonces, como se comprueba en la adquisición del castillo de Dueñas entre 1190 y $1201^{90}$. Del estudio de estos y otros documentos similares, se deduce que muchos de estos caballeros estuvieron interesados en mantener relaciones con la Orden por diversos motivos, pero no deseaban hacer profesión en ella (por estar casados, o por otra causa), por lo que optaron por la familiatura, a cambio hacían donaciones piadosas con reserva del usufructo vitalicio de los bienes donados. A veces, a falta de donaciones, es la propia Orden la que hace cesión temporal (encomienda) de algunos de sus lugares para su repoblación, y recurre también a la fórmula del prestimonio que contiene cláusulas similares a las de los contratos agrarios. Es probable incluso que el origen de las encomiendas, institución fundamental en la organización interna de la Orden y en la administración de su patrimonio, estuviera relacionado con la concesión de prestimonios sobre ciertos bienes donados por particulares con reserva de usufructo vitalicio, que adquirirían así el carácter de bienes encomendados que debían revertir íntegramente a la Orden a la muerte de sus donantes. Algunas de estas donaciones son realmente prendas de préstamos encubiertos motivados por situaciones de necesidad de sus propietarios. Es sabido que la guerra resultó un estímulo para las relaciones económicas, muchos caballeros de la frontera tuvieron que empeñar sus castillos para participar en las grandes campañas y recurrieron a la fórmula de donación con reserva de usufructo como prestimonio vitalicio. Las Ordenes aceptaron estas propuestas y adaptaron su organización interna a esa situación

87 Doc. de fecha 1181, septiembre 29, Cuéllar (probablemente), publ. GoNZÁLEZ, J. 1960, op. cit. vol. III, $\mathrm{n}^{\circ} 933$.

${ }_{88}$ Bulario de Calatrava, p. 7. Doc. de fecha 1168 , marzo 27.

${ }^{89}$ Bulario de Calatrava, doc. de fecha 1181 , enero 3 p. 16

$90 \mathrm{El}$ caso fue estudiado de forma monográfica por J. O'Callaghan, pues el castillo de Dueñas fue probablemente el antecedente del posterior castillo de Calatrava la Nueva, refundado en 1217, «Sobre los orígenes de Calatrava la Nueva» en Hispania XXIII (1963) pp. 494-504. Vid. doc. de fecha 1190, noviembre 22 en AHN Calatrava, carpeta 456, $\mathrm{n}^{\circ} 29$, y doc. de fecha 1201, enero 16 , publ. en Bulario de Calatrava, p. 35

Hispania, LXII/1, núm. 210 (2002) 9-40 
La Orden de Santiago fue fundada en el reino de León por Fernando II el año 1170. El hecho debe relacionarse con la proclamación de la mayoría de edad de Alfonso VIII de Castilla en 1169 y la salida al exilio del caballero castellano Fernando Rodríguez de Castro, desnaturalizado en León por su enfrentamiento con los Lara y vinculado previamente con la Orden de Calatrava ${ }^{91}$. También se señalan como precedentes leoneses la existencia de una Hermandad de fratres en Ávila y la fundación en 1169 de la Hermandad de freiles de Cáceres, que fue el germen sobre el que directamente se creó la nueva Orden.92 Su primer Maestre fue D. Pedro Fernández, que suscribió un pacto de sociedad con el arzobispo de Santiago de Compostela, por el que se le ofrecía el patronato del apóstol Santiago y se le encomendaba la conquista de los castillos de Alburquerque, Coria y Cáceres ${ }^{93}$. La bula fundacional de la Orden data de 1175 y fue emitida por Alejandro III $^{94}$. Por este mismo documento sabemos que, en el orden interno, la Milicia de Santiago estuvo integrada por freiles clérigos y laicos. Estos últimos no hacían voto de castidad, por lo que podían casarse y tener hijos e impulsaron el desarrollo de la vida caballeresca. Además del Maestre y el Capítulo General, la Orden contaba con un consejo de Trece caballeros como órgano de gobierno colegiado en momentos de crisis. La Orden de Santiago mantuvo una fuerte dependencia política del reino de León, sin embargo también tuvo una importante presencia en otros reinos, como Portugal y Castilla, a menudo enfrentados entre sí, motivo por el cual su casa de Uclés gozó de gran autonomía, en una situación similar a la de otros grandes señoríos de la frontera.

Como ya hemos dicho, en 1174 Alfonso VIII hizo donación a la Orden de la villa y castillo de Uclés95, que sería sede de una encomienda y un Priorato y cabeza de los caballeros de Santiago en Castilla. La encomienda de Uclés comprendía las tierras de un antiguo distrito islámico más algunos otros castillos de la zona como Alharilla ${ }^{96}$, importante vado sobre el Tajo que canalizaba el tráfico de recuas, ganados y sal procedente de las salinas de Belinchón, y los castillos de Oreja ${ }^{97}$ y $\mathrm{Mora}^{98}$, ya en los Montes de Toledo. En total comprendía un territorio de $4.684 \mathrm{~km}^{2}$, con tres encomiendas y unos diez castillos en la llanu-

91 J. L. Martín afirma que «la Orden es creada por personas relacionadas con Fernando Rodríguez de Castro, el rebelde castellano, y con Armengol VII de Urgel, los dos grandes caudillos de Fernando II. Estos personajes, o tal vez el mismo rey, utilizarían para sus propios fines la Orden nacida con más altos objetivos, y harían de una institución religiosa un instrumento militar al servicio de sus objetivos personales». MARTín, 1974, op. cit. p. 7.

92 Vid. el relato de la fundación en LOMAX, D. 1965, pp. 4 y ss y MARTín, J:L:1974, p. 17.

93 Doc. de fecha 1171 , febrero 12, pub. MARTín, op, cit. $\mathrm{n}^{\circ} 42$.

94 Publ. por Martín, doc. $\mathrm{n}^{\circ} 73$.

95 Martín, doc. $\mathrm{n}^{\circ} 66$.

96 Donación de Alfonso VIII en 1172, febrero 1, publ. MARTín, doc. $n^{\circ} 52$, el arancel de Alharilla doc. $\mathrm{n}^{\circ} 58$

97 Id. de fecha 1171, septiembre 11, publ MARTín, doc. $\mathrm{n}^{\circ} 47$

98 Id. de fecha 1171, marzo 23, publ por GoNZÁLEZ, 1960, op. cit. vol. II pp. 268-270.

Hispania, LXII/1, núm. 210 (2002) 9-40 
ra de la Mancha y, hacía 1184, recibió el privilegio que le reconocía el derecho de conquista sobre el Campo de Montiel, futura área de expansión por el sur ${ }^{99}$. La Orden de Santiago desarrolló una importante labor asistencial y mercedaria en la frontera, para lo que destacaron sus hospitales de Toledo ${ }^{100}$, Cuenca ${ }^{101}$, Alarcón ${ }^{102}$ y otros. La documentación conservada al respecto muestra que también se realizaron prestimonios y encomendaciones con caballeros particulares para la fundación y mantenimiento de estos hospitales y casas de redención de cautivos.

La Orden de San Juan estuvo presente en los reinos peninsulares desde principios del siglo XII ${ }^{103}$. Alfonso VII y Alfonso VIII la acogieron bajo la protección real y le concedieron privilegios de exención de cualquier otro señorío ${ }^{104}$. Esta Orden pareció destacar en principio por su función asistencial, aunque también hay indicios de su participación en determinadas campañas militares. La explotación de sus dominios se orientó hacia la ganadería preferentemente y su asentamiento en la frontera castellana fue tardío. Hacia mediados del siglo XII se registran diversas concesiones reales relativas a los castillos de Alcázar ${ }^{105}$ y Consuegra a favor de pequeños caballeros de la frontera. Es posible que alguno de éstos, como Rodrigo Rodríguez, fuera sanjuanista o tuvieran relación con la Orden ${ }^{106}$. La primera donación hecha directamente en favor de la Orden de San Juan en la zona data de 1162 y se refiere a cuatro castillos que formaban el distrito de Campo de Criptana, en plena llanura manchega ${ }^{107}$; no obstante la Orden cedió su tenencia en prestimonio al caballero mozárabe toledano Miguel Asarafí. Finalmente, recibió en 1183 el castillo de Consuegra con sus portazgos, que fue sede de una encomienda y asiento futuro de su Gran Priorato en Castilla ${ }^{108}$. El castillo de Consuegra poseía un distrito de $2.845 \mathrm{~km}^{2}$ de superficie y se encontraba por entonces in frontaria maurorum, pues iba desde los Montes de Toledo hasta la cabecera del Guadiana, lindando por el sur con el distrito de Alhambra, en el Campo de Montiel, en poder islámico hasta las Navas. No obstante, su dominio era bastante más reducido que el de las otras dos Órdenes estudiadas, a juzgar por el número de castillos que comprendía, sólo cinco, y por la falta de privilegios relativos a las

99 La noticia la da RADES, Chrónica de Sanctiago... fol. 17.

100 Fundado en 1180 según doc. publ por GonZÁLEZ, J. 1960, vol II, pp. 598-599.

${ }_{101}$ Id. en 1182 según doc. publ. por MARTíN, 1974, op. cit. n 138.

102 Referencia de dicho hospital en RADEs Chronica de Sanctiago... fol. 19.

103 García Larragueta, S.A. «La Orden de San Juan en la crisis del Imperio Hispánico del siglo XII» en Hispania 49 (1952) pp. 483-524.

104 Vid. priv. de 1170, publ. Libro de Privilegios de San Juan..., 1995 op. cit. doc. $\mathrm{n}^{\circ} 106$

${ }_{105}$ Doc. De fecha 1150, publ en el Libro de Privilegios de San Juan... , 1995 op. cit. doc. $n^{\circ} 56$

${ }^{106}$ MOLero García, J.M. «La frontera castellana en tiempos de Alfonso VII: Nobleza y organización del espacio» en II Estudios de Frontera. Actividad y vida en la Frontera. Jaén 1998, pp. 585-601.

107 Doc. publ. por GONZÁLEZ, J. 1960, op. cit. vol. II $n^{\circ} 54$.

${ }^{108}$ Libro de Privilegios de San Juan..., 1995 op. cit. doc. $\mathrm{n}^{\circ} 144$. 
cabalgadas o el botín. La Orden de San Juan también cedió en encomienda la tenencia de sus castillos a caballeros durante los primeros años de asentamiento en la frontera, mientras que los freiles se ocuparon preferentemente de la repoblación de sus aldeas.

Como recapitulación de todo lo expuesto hasta aquí, cabe decir que la corona concedió privilegios de carácter militar a la Orden de Calatrava principalmente, en menor medida a la de Santiago, y muy pocos o ninguno a la de San Juan, por los que se reconocía el derecho de conquista sobre los castillos:

«...Ego Ildefonsus... dono vobis \& concedo, ut omne castellum, quod de saracenis deinceps, quolibet modo acquirere potueritis, pro hereditate illud habeatis semper, \& cum eo mihi, ut Regi, \& Domino serviatis»109.

Además les concedió los derechos reales sobre el quinto del botín y el diezmo real sobre los portazgos de las recuas y las parias de las tierras de los moros ${ }^{110}, \mathrm{y}$ la mitad de los rescates de los cautivos que valiesen más de $1.000 \mathrm{mrs}^{111}$.

Hacia 1190 los dominios de las Órdenes Militares en la Mancha comprendían en conjunto unos $20.000 \mathrm{Km}^{2}$ sobre los cuales se asentaban unos 25 castillos, lo que indica la vasta extensión del territorio y el escaso desarrollo del poblamiento. A cada castillo le correspondería como media un territorio de unos $800 \mathrm{~km}^{2}$. Cómparese esta situación con la de la frontera catalana, por ejemplo, en donde en el territorio comprendido entre las desembocaduras del Llobregat, al sur de Barcelona, y el Francolí, en Tarragona, de poco más de $2.000 \mathrm{~km}^{2}$, había el mismo número de 25 castillos, por lo que correspondía a cada uno alrededor de $100 \mathrm{~km}^{2112}$.

Los castillos de las Órdenes Militares en la Mancha se localizaban junto a las vías de comunicación y los escasos cursos fluviales de la zona y tenían como finalidad principal, además de garantizar la seguridad del territorio, controlar el tráfico de personas, mercancías y ganados, recaudar portazgos y regular el aprovechamiento de las dehesas. También tuvieron las Órdenes castillos en la zona del Tajo, especialmente fuera de la tierra de Toledo entre Aceca y Zorita que controlaban los principales vados sobre este río, por donde pasaban caballeros y ganados procedentes de los concejos castellanos serranos.

Las Órdenes, al igual que algunos concejos de las extremaduras, suscribieron entre sí diversas cartas de Hermandad y conveniencias, en unos casos con una finalidad militar y, en otros simplemente para definir el alcance de sus de-

109 Bulario de Calatrava, doc. de fecha 1173, junio 28.

110 Bulario de Calatrava, doc. de fecha 1175, marzo 8, p. 11.

111 AHN Calatrava Lib. $1.341 \mathrm{c}$ bis fol $45 \mathrm{r}^{\circ}$, doc. de fecha 1183, diciembre 2 .

112 Vid. mapa publicado por Udina, según estudios de D'Abadal, en Historia de España de Espasa-Calpe, tomo IX, 1998, pp. 368.

Hispania, LXII/1, núm. 210 (2002) 9-40 
rechos señoriales en distintos lugares ${ }^{113}$. Los conflictos con la mitra toledana en el ejercicio del privilegio de exención canónica propio de las órdenes regulares, así como la conveniencia de defender conjuntamente sus derechos ante la $\mathrm{Cu}$ ria, les animaron también a actuar de forma concertada. La intervención de la Corona en estos asuntos para facilitar la consecución de concordias, ${ }^{114}$ nos induce a pensar que las Hermandades pudieron ser propiciadas por la monarquía con una finalidad política.

En las zonas más pobladas, como el valle del Tajo y la serranía conquense se desarrollaron las villas, produciéndose al mismo tiempo la decadencia y transformación de los antiguos castillos. Algunas se organizaron como concejos, se dotaron de fueros como el de Huete ${ }^{115}$, Uclés ${ }^{116}$ y Cuenca ${ }^{117}$, y delimitaron sus alfoces que se configuraron a modo de grandes corredores en sentido longitudinal para un mejor aprovechamiento de los pastos, estableciendo medianeros y montanerías entre sí. Las Órdenes Militares facilitaron el adehesamiento de sus tierras y su explotación como pastos de invierno para los ganados de los concejos y señoríos de la sierra. Ellas mismas dispusieron de una importante cabaña ganadera a fines del XII; pero su labor principal fue la regulación, junto con la Corona, del tránsito de ganados y mercancías, la recaudación de peajes y el arrendamiento de pastos a los ganados trashumantes, como veremos más adelante.

En los fueros de fines del XII se aprecia una tendencia hacia la fusión de la doble tradición jurídica castellana y mozárabe, para dar lugar al denominado derecho de las extremaduras. La comunidad vecinal gozaba de una cierta autonomía para poder elegir a sus autoridades concejiles, que eran ratificadas después por el señor a cambio de un tributo. La guerra seguía siendo una activi-

113 La primera carta de hermandad data de 1178 y fue suscrita entre las Órdenes del Hospital, el Temple y Santiago, publ. por Martín, Santiago, op cit. doc. 92, p. 273. La Orden de Santiago estableció una societas con la de Calatrava en 1182, MARTín, 1974 op. cit. doc. $n^{\circ} 145$, y una conveniencia más amplia en 1188 , ibid. doc. $\mathrm{n}^{\circ} 240$. Vid. el estudio al respecto de O'Callaghan, J. "Hermandades between the Military Orders of Calatrava and Santiago, during the Castillian Reconquest, 1158-1252» en Speculum XLIV (1969) pp. 609-618.

114 La concordia entre el arzobispado de Toledo y la Orden de Santiago se alcanzó hacia 1180 , según doc. publ. por MARTín con el $n^{\circ} 117$; el acuerdo entre Toledo y Calatrava es de 1181, publ. GoNZÁLEZ, vol. III, doc. $n^{\circ}$ 932, en ambos casos la iniciativa para la negociación se debió a Alfonso VIII.

115 RIVERA GARRETAS, M. apunta la posibilidad de que el calificativo óptimo que aparece en el protocolo del fuero de Belinchón, sea una errata por Opte, Huete, y que fuera esta localidad la que introdujera en primer lugar el fuero de Sepúlveda en la zona, "El fuero de Uclés (siglos XII-XIV)» en Anuario de Historia del Derecho Español LII (1982) pp. 243-348.

116 El fuero de Uclés fue estudiado en primer lugar por F. FITA y más recientemente por RIVERA GARRETAS, vid. nota anterior.

117 Hay numerosos estudios de este fuero extenso que puede ser considerado la máxima expresión del derecho foral en las extremaduras. Recientemente se ha señalado su relación con el precedente fuero breve de Uclés, vid. BARRERO GARCíA, A.M. «El proceso de formación de los fueros municipales» en Alvarado Planas, J. Coord. Espacios y fueros... 1995, op. cit. pp. 59-88. 
dad tradicional, de ahí que en muchas comunidades vecinales se divida el cuerpo social en dos categorías: caballeros y peones, como se dice en el fuero de Cuenca. Pero las cabalgadas se van haciendo cada vez menos frecuentes y, en su lugar, empieza a extenderse la esculca, es decir la salida en vigilancia de los rebaños trashumantes durante períodos prolongados ${ }^{118}$. En las villas se configura una sociedad campesina compuesta por yugueros, medio yugueros, quiñoneros, braceros, atemplantes y moros en el escalón inferior que viven en una situación próxima a la esclavitud. Asimismo, los textos contienen las primeras descripciones de los paisajes agrarios en donde vemos huertas, viñedos, cultivos de secano ad anni vicem, ejidos, montes y dehesas ${ }^{119}$.

En la vega del Tajo, donde la presencia mozárabe es mayor, se aprecia una intensificación del mercado de la tierra y un gran desarrollo de los cultivos. La tradición islámica del Liber es importante, como se aprecia en la difusión del derecho de marjadraque ${ }^{120}$, una cláusula de garantía para el comprador en los contratos mercantiles anterior a la robra, que empieza a extenderse en esta época. Proliferan las compra-ventas, los arrendamientos, los pagos aplazados, el crédito en general, y diversos tipos de contratos agrarios como signo claro de la vitalidad de la sociedad civil, inmediatamente después de que la frontera se trasladara al sur de los Montes de Toledo. Las Órdenes Militares no fueron ajenas a este tipo de negocios para impulsar la repoblación de sus tierras. Muchas donaciones piadosas hechas a su favor revertían sobre el donante que, como precarista, recibía el usufructo vitalicio de las tierras. Algunas donaciones de particulares o concesiones en prestimonio de las Órdenes contienen cláusulas propias de los contratos agrarios ad laborandum con el fin de mejorar la capacidad productiva de las tierras ${ }^{121}$. En otras, las Órdenes simplemente prestaban dinero a los particulares para mejorar sus cultivos y obtenían un beneficio por ello ${ }^{122}$. También hay acuerdos con particulares sobre molinos por los que se

118 Riv, M. «Agricultura y ganadería en el fuero de Cuenca» en Anuario de Estudios Medievales 12 (1982) pp. 167-181

119 Vid. a título de ejemplo los fueros de Dos Barrios y San Silvestre. El fuero de Dos Barrios fue concedido en principio por tres caballeros hermanos, Rodrigo, Pedro «I don» Riquer, después fue ratificado por el rey. El Fuero de San Silvestre fue concedido en época desconocida por el caballero Munio Macho y más tarde fue ratificado por el Maestre de Calatrava en 1198. El lugar de San Silvestre se encontraba situado cerca de Maqueda. ref. AHN Órdenes Militares Calatrava Lib. 1.341 $c$ bis fol $81 r^{\circ}$.

${ }^{120}$ Fue estudiada por FITA, F. «Marjadraque según el fuero de Toledo» en Boletín de la Real Academia de la Historia 7 (1885) pp. 360-394.

121 Tal es el caso del lugar de Alboer (Villamanrique), donado en primer lugar por el rey al conde Ponce de Minerva, éste a su vez se lo dio a Oth, conde de Almería y, por último, éste lo cedió al mozárabe Sancho Cochar. Este lugar pasaría después al señorío santiaguista, Vid. doc. de fecha 1161, publ . MARTín, 1974, doc. n $^{\circ} 29$

122 Vid. los documentos referentes a los hermanos Gonzalo y Remón sobre los lugares de Mochales y Bitel y la intervención de la Orden de Calatrava en la contratación de un préstamo. Doc. de

Hispania, LXII/1, núm. 210 (2002) 9-40 
cedían los derechos de explotación a cambio de su construcción o labores de reparación y mantenimiento ${ }^{123}$. Como es sabido, en los molinos se realizaba una actividad industrial, pero también eran un centro de préstamo rural y un monopolio señorial que se podía defender transformando sus instalaciones en una casa fuerte. En los arrendamientos a particulares se tuvieron en cuenta todas estas circunstancias. El caso de los castillos tuvo un significado especial por su importancia política y militar. Como ya hemos comentado más arriba, se constata que algunos caballeros propietarios de castillos los hipotecaban para financiar sus actividades militares ${ }^{124}$, o bien para acceder a la familiatura con alguna Orden que pasaba a ser su acreedora. A su muerte, los herederos estaban obligados a cancelar la deuda o ceder la propiedad del castillo. En ocasiones la propia Orden estaba interesada en renegociar el préstamo, con el fin de asegurar el mantenimiento de los castillos por particulares.

Las diferencias entre los distintos reinos hispano-cristianos fueron en aumento a fines del XII, especialmente entre Castilla y León. Los almohades trataron de administrarlas a su favor por medio de una política de treguas y alianzas que les diera cierta ventaja en el contexto peninsular ${ }^{125}$. La idea de cruzada estaba en crisis en el conjunto de Occidente; la derrota de Hattín (1187) y la utilización política que se hizo de este movimiento, hacían presagiar un traslado de sus objetivos al espacio europeo ${ }^{126}$. España se convirtió en tierra de cruzada y al mismo tiempo se reforzaron las corrientes de integración política entre sus reinos.

Los conflictos fronterizos evolucionaron hacia una crisis general que se hizo patente después de la derrota castellana de Alarcos el año 1195. Los almohades entendían la guerra en la península como un asunto de estado, por lo que habían sido partidarios de mantener en paz sus fronteras por medio de treguas, hasta que consideraron llegado el momento propicio para realizar una gran

feha 1199, abril 30, AHN, OOMM Calatrva Lib. 1.341 c fol. 141, y Doc. de fecha 1202, julio, Lib. $1.342 \mathrm{c}$, fol. 8.

123 Vid. contratos para la construcción de molinos en el Júcar en 1185 , enero 23 y 24, publs. MARTín, docs. $\mathrm{n}^{\circ} 175$ y 176 .

124 Vid. el préstamo sobre los castillos de Huélamo y Monteagudo de fecha 1177, publ. por RIVERA GARRETAS, 1985 , op. cit. apéndice doc. $n^{\circ} 77$

125 Cfra. Los trabajos de Julio González sobre los reinados de Alfonso VIII de Castilla y Alfonso IX de León, además puede consultarse una síntesis en LADERO QUESADA, M.A. coord. La reconquista $y$ el proceso de diferenciación política (1035-1217). Tomo IX de la Historia de España, Ramón Menéndez Pidal. Ed. Espasa-Calpe, Madrid 1998.

126 STRAYER, J. "The political Crusades of the Thirteenth Century» en SETtON, K.M. ed. $A$ History of the Crusades vol. II, Londres 1969. Más reciente GARCíA-GuIJARRO, L. "Cruzadas políticas, una denominación cuestionable» en Papado, Cruzadas y Órdenes Militares, siglos XI-XIII Madrid 1995, pp. 264-266. 
campaña contra el reino de Toledo de efectos duraderos, para ello reforzaron sus alianzas políticas y movilizaron grandes contingentes de tropas. Alfonso VIII, en cambio, trataba de evitar las grandes batallas y se mostraba partidario de una guerra de desgaste permanente, animando a ello a las milicias concejiles y otros señores poderosos de la frontera. En cualquier caso, lo más frecuente fue la existencia de un sistema de treguas que equilibrase la situación. Las treguas entre castellanos y almohades quedaron interrumpidas en $1194^{127}$, y el califa Abu Yusuf Yaqub realizó al año siguiente la victoriosa campaña de Alarcos, contando con el apoyo directo del caballero castellano desnaturalizado D. Pedro Fernández de Castro y sus mesnadas ${ }^{128}$, y la connivencia de los reinos de León y Navarra. Tras esta batalla, la frontera volvió a la línea de los Montes de Toledo, la Orden de Calatrava perdió todo su campo ${ }^{129}$ y sufrió una profunda crisis interna que la llevó, prácticamente, a su desaparición. De hecho entre 1198 y 1211 los diplomas y privilegios de la Orden llevan el título de Orden de Salvatierra, pues así se llamaba el castillo sobre el que se asentaban los escasos caballeros que todavía tenía el instituto, perdido el dominio sobre Calatrava ${ }^{130}$. En los casos de Santiago y San Juan, la derrota supuso una contención de las fronteras y un cierto retroceso del proceso repoblador en sus encomiendas de Uclés y Consuegra. Pero no hubo pérdidas significativas del dominio territorial y tampoco sufrieron una crisis tan aguda como la de Calatrava. Tras algunas campañas de castigo posteriores a la batalla de Alarcos, Alfonso VIII y el Miramamolín acordaron de nuevo treguas entre 1197 y $1210^{131}$, lo que proporcionó cierta tranquilidad necesaria para el reino de Castilla.

Durante este tiempo, el papado desarrolló en la península una verdadera campaña de cruzada y forzó el abandono de la alianza leonesa y navarra con los musulmanes, impulsando en cambio la reconstrucción de la unidad entre los reinos hispanocristianos. El rey de Aragón no respetaba las treguas con los almohades y apoyaba abiertamente la presencia de un poder almorávide residual en las Baleares ${ }^{132}$. Algunos caballeros calatravos tampoco aceptaban las treguas ${ }^{133}$ y ocuparon el castillo de Salvatierra, por entonces en campo enemigo, desde donde hostigaban a los musulmanes. Dada esta situación, era fácil prever

${ }^{127}$ Huici Miranda, A. Colección de Crónicas árabes de la Reconquista, vols. II Y III Al-Bayan Al-Mugrib fi ijtisar ajbar muluk al-Andalus wa Al-Magrib. Tetuán 1953 y 1954, pp. 180-181.

128 GoNZÁleZ, J. Alfonso VIII... op. cit. vol. I pp. 321 y ss.

129 Según relato de al-Himyari apud. VIgueRA Molins, M.J. Coord ${ }^{\mathrm{a}}$ y Prólogo, El retroceso territorial de al-Andalus. Almorávides y almobades. Siglos XI al XIII. Tomo VIII-II de la Historia de España, Ramón Menéndez Pidal. Ed. Espasa-Calpe, Madrid 1997, p. 98.

130 RADES y ANDRADA, Chronica de Calatrava... fols. 20 al 26.

131 JIMÉNEZ DE RADA, Lib. VII, Cap. XXX.

132 GoNZÁLEZ, J. Alfonso VIII, op. cit. vol. I o. 986 y ss.

${ }_{133}$ Cfra. Bula de Inocencio III de 1205, animando a los calatravos a ir a la frontera para luchar contra los musulmanes, publ. en MIGNE, Patrologia Latina, vol. 215.

Hispania, LXII/1, núm. 210 (2002) 9-40 
una reanudación de las hostilidades. En 1211 los almohades conquistaron Salvatierra $^{134}$ y Alfonso VIII convocó la hueste para el año siguiente.

La campaña de las Navas de Tolosa (1212) se desarrolló con gran éxito para los reinos hispanocristianos. Las huestes de las Órdenes Militares participaron en la batalla formando un haz junto con las principales mesnadas de la nobleza castellana. Las milicias de los concejos de la transierra también estuvieron presentes formando haz con las tropas navarras. Entre las dos, probablemente, suponían la novena parte de las tropas movilizadas ${ }^{135}$, lo que resulta limitado si se compara con las mesnadas de la nobleza y los caudales aportados por el arzobispo de Toledo. Durante la campaña se reconquistó todo el Campo de Calatrava, que se devolvió a dicha Orden, a excepción del castillo de Salvatierra que continuó en manos musulmanas ${ }^{136}$. En 1213, una nueva campaña de Alfonso VIII con apoyo de los caballeros de Santiago, conquistó el Campo de Montiel que pasó a integrar el señorío de dicha Orden, y Alcaraz, que quedó para el arzobispo de Toledo ${ }^{137}$. Este mismo arzobispo reconstruyó el castillo de Milagro, en los Montes de Toledo ${ }^{138}$, desde donde se preparaba para recuperar los pastizales de Capilla. La fortaleza de Calatrava, muy destruida por el asedio sufrido, fue abandonada por la Orden que trasladó su casa central a Calatrava la Nueva, cuya construcción se inició en $1217^{139}$, comenzando así una nueva época. La nueva frontera se situó al sur de Sierra Morena, aunque todavía permanecieron algunos enclaves musulmanes al norte de esta línea, como Salvatierra y Capilla, que pertenecieron al rey de Baeza hasta que los entregó por pacto en $1225^{140}$, y al año siguiente fue anexionado dicho reino a Castilla por Fernando III, dentro ya de las operaciones previas a la conquista de Córdoba.

A continuación se reanudó la repoblación en tierras de la Mancha, recuperándose rápidamente las pautas anteriores. Hubo un relanzamiento de los señoríos de Órdenes y se definieron de forma más precisa los límites de sus dominios respectivos, en donde propiciaron el desarrollo de las villas mediante la concesión de fueros de población. En relación con esta política hubo una redistribución de la población, constatándose el abandono de lugares habitados tra-

${ }^{134}$ Colección de Crónicas árabes de la Reconquista. Vol. II Al-Bayan al-Mugrib Fi Ijtisar ajbar muluk al-Andalus wa al-Magrib. Por Ibn Idari al-Marrakusí. Los almobades. Trad. de HuiCi MiRANDA, A. Tomo I, Tetuán 1953, pp. 265 y ss.

135 Sobre la batalla de las Navas vid. Huici MiRANDA, A. Las grandes batallas de la Reconquista durante las invasiones africanas (almorávides, almobades, benimerines), Madrid 1956 pp. 219-320. Una revisión reciente en ALVIRA CABRER, M. «La muerte del enemigo en el pleno medievo: cifras e ideología (El modelo de Las Navas de Tolosa)» en Hispania LV/2 n 190 (1995) pp. 403-423. El cálculo sobre los efectivos aportados por las OOMM en nuestro trabajo RUIZ GÓMEZ, F. «La hueste de las Órdenes Militares...» op. cit. p. 422.

136 JIMÉNEZ DE RADA, Lib. VIII, caps. V y VI.

137 Según datos aportados por Crónica Latina, p. 26, y JIMÉNEZ DE RADA, Lib. VIII, cap. XIII.

138 GONZÁlEZ, J. 1960, vol. III, doc. nº 965.

139 RADES Y ANDRADA, fol. $33 \mathrm{r}^{\circ}$

${ }_{140}$ Crónica Latina, p. 65. 
dicionalmente y el impulso de otros nuevos. Los casos más notables en el Campo de Calatrava fueron los de Calatrava la Vieja-Calatrava la NuevaAlmagro ${ }^{141}$, y el de Alarcos-Villa Real. También se constata la recuperación de la sociedad de labradores, tal y como se ha descrito a fines del XII, y de los paisajes agrarios, ahora con una mayor difusión e intensidad. Pero sobre todo destaca la importancia de las dehesas y el auge de la economía ganadera, llegándose a impedir la realización de nuevas pueblas cerca de Milagro, en la zona de los Montes o en el Valle de los Perales, en las estribaciones de Sierra More$\mathrm{na}^{142}$. En relación con los rebaños y los pastos hubo un desarrollo de la vida pastoril, al tiempo que se extendía la presencia de colmeneros y loseros en los montes, lo que condicionó el desarrollo social posterior en esta tierra. Fernando III y Alfonso $\mathrm{X}^{143}$ de acuerdo con los grandes señores de la zona, como el arzobispado y la ciudad de Toledo y las Ordenes Militares, establecieron una regulación centralizada de los portazgos en la zona del Tajo y promovieron el trazado de las cañadas para un mejor aprovechamiento de los pastos del Guadiana y de las sierras del sur.

La victoria de las Navas tuvo consecuencias muy importantes para la expansión de los señoríos de las Órdenes en la Mancha, como ya se ha dicho. La Orden de Calatrava experimentó una verdadera refundación, recibiendo para ello distintos privilegios reales ${ }^{144}$ y bulas pontificias ${ }^{145}$. Por una parte tendió a crear un marco de entendimiento y cooperación con las otras Órdenes mediante la suscripción de nuevas hermandades entre 1220 y $1225^{146}$. Después se acometió una redefinición del marco señorial estableciéndose diversos deslindes y mojonerías de sus dominios: en 1232 entre Calatrava y San Juann ${ }^{147}$, en 1237

${ }^{141}$ O'Callaghan, J. «Sobre los orígenes de Calatrava la Nueva» en Hispania XXIII (1963) pp. 494-504. Sobre Almagro vid. CORCHADO SORIANO, M. Estudio bistórico-económico-jurídico del Campo de Calatrava. Parte III, Los pueblos y sus términos. Ciudad Real, 1982, pp. 61 y ss.

${ }_{142}$ Privilegio real de confirmación de la concordia sobre divisoria de términos entre Toledo y la Orden de Calatrava de fecha 1269, agosto 24. Publ. Bullarium... de Calatrava, ed. cit. p. 133.

${ }_{143}$ Vid. por ejemplo, para la ciudad de Toledo, el privilegio de fecha 1255, mayo 22, por el que Alfonso X ordena que sólo cobren dos montazgos, uno en Milagro y otro en Cíjara. Publ. IzQUiERDO BENITO, R. Privilegios reales... de Toledo, 1990, op. cit. doc. $n^{\circ} 28$. Hay privilegios similares para las tres Órdenes Militares.

${ }_{144}$ Confirmación de 30 privs. anteriores de la Orden de Calatrava por Fernando III de fecha 1220, abril 16, publ. Bulario... de Calatrava, p. 49.

${ }_{145}$ Cuarta bula confirmatoria de la Orden de Calatrava de fecha 1214, mayo 20, Publ. Bulario... de Calatrava p. 42.

146 O'CAllaghan, J. «Hermandades between the Military Orders of Calatrava and Santiago, during the Castillian Reconquest, 1158-1252» en Speculum XLIV (1969) pp. 609-618.

147 Publ. Bulario... de Calatrava p. 64. 
entre Santiago y San Juan ${ }^{148}$, y en 1239 entre Calatrava y Santiago ${ }^{149}$. Finalmente se renovó la concordia con el arzobispado de Toledo en $1245^{150}$.

La Orden de Calatrava recuperó el dominio sobre el Campo de Calatrava de unos $13.500 \mathrm{Km}^{2} \mathrm{y}$, aunque no pudo ampliarlo con nuevas tierras, por la presencia de otros señoríos importantes en su entorno, sí intensificó su poblamiento. Hacia 1230 se comprueba la existencia de una red de encomiendas calatravas bastante estructurada. En total se conocen 11 encomiendas en el Campo de Calatrava que contaban con 12 castillos y más de cincuenta lugares poblados, lo que seguía siendo insuficiente dada la magnitud del territorio. El poblamiento seguirá en aumento, aunque de forma muy lenta, hasta el final de la edad media, al tiempo que se fue incrementando el número de encomiendas por subdivisión de las existentes ${ }^{151}$. El patrimonio de la Orden continuó enriqueciéndose con las donaciones de particulares, consistentes ahora normalmente en un quinto de sus bienes, sobre los que se acostumbraba a realizar la conocida reserva de usufructo vitalicio. Para su gestión se siguió practicando la cesión en prestimonio a particulares, aunque poco a poco se impuso la gestión directa a través de las encomiendas.

La Orden de San Juan había adquirido un notable poder político gracias a su mediación en los últimos conflictos habidos entre León y Castilla. Tras las Navas recibió la heredad de Cortes cerca de Alcaraz en $1214^{152}$ y amplió su dominio hasta Ruidera, donde recibió en 1215 la donación real de los llamados cuatro castillos del Guadiana ${ }^{153}$, aunque tuvo que ceder Villarrubia a Calatrava, al sur de la sierra de la Calderina, y Criptana a Santiago. En general su campo creció en un tercio de su superficie, llegando casi hasta los $4.000 \mathrm{Km}^{2}$, con 8 castillos y más de 20 lugares poblados. Además de las hermandades, deslindes y concordias ya mencionadas, la Orden de San Juan promovió la explotación de sus dehesas en los Montes de Toledo y en la cabecera del Guadiana, y estableció un portazgo en Consuegra ${ }^{154}$. No obstante las posibilidades de desarrollo de la economía ganadera en sus dominios eran menores, pues no tuvo acceso a los grandes pastizales de las sierras del sur, salvo en su pequeña heredad de Cortes, cerca de Alcaraz. Tampoco parece que desarrollara una importante actividad financiera en forma de créditos; pero sí se constata su interés para promover la repoblación de sus villas. Para ello concedió cartas pueblas a 15 lugares del Campo de San Juan, con características de contratos agrarios

${ }^{148}$ Libro de Privilegios de San Juan, op. cit. 1995, doc. $\mathrm{n}^{\circ} 267$.

149 Publ. Bulario... de Calatrava p. 686.

150 Publ. Bulario... de Calatrava p. 78.

151 Presentamos sólo las pautas generales del poblamiento en la zona, un estudio detallado de las encomiendas puede verse en CORCHADO SORIANO, La Orden de Calatrava y su Campo, Ciudad Real 1982-1984, 3 vols. Y en Rodríguez PiCAVEA, 1994, op. cit. pp. 61-100.

152 Libro de Privilegios de San Juan, op. cit. 1995, $\mathrm{n}^{\circ} 210$.

153 Ibid. $\mathrm{n}^{\circ} 215$.

${ }^{154}$ Doc. de fecha 1200, publ. Libro de Privilegios de San Juan, 1995, n 191

Hispania, LXII/1, núm. 210 (2002) 9-40 
colectivos en los que se asignaba un número total de pobladores, se fijaba el importe global de las rentas y se otorgaba el régimen foral de Consuegra ${ }^{155}$. La documentación de San Juan muestra, a diferencia de las otras dos Órdenes, la existencia de un régimen señorial más estricto en las villas de su campo.

La Orden de Santiago sufrió una profunda crisis política a fines del XII a causa de la alianza entre el rey de León y los almohades, que llevó a la encomienda y Priorato de Uclés a adoptar una actitud de práctica independencia ${ }^{156}$. Tras la campaña de las Navas y la conquista del Campo de Montiel en 1213, estos territorios se integraron en el señorío de la Orden, primero a través de un prestimonio acordado con D. Álvaro Núñez de Lara, uno de sus principales benefactores por entonces ${ }^{157}$. Cuando este linaje empezó a declinar, por su oposición a la entronización de Fernando III, fue la propia casa real la que administró estos prestimonios, hasta que de nuevo fueron reintegrados a la Orden en $1227^{158}$, época en la que los dominios santiaguistas se extendían ya por la Sierra de Segura. El Campo de Santiago en la Mancha había duplicado su extensión comprendiendo $10.170 \mathrm{~km}^{2}$, una veintena de castillos y numerosas villas localizadas preferentemente al norte, cerca de Uclés, mientras que las llanuras del sur tendrán que esperar a una repoblación tardía que se inicia en el XIV y continuaba todavía en el XVI. También recibieron los santiaguistas la sierra de Segura, que pasaría a convertirse en cabecera de su casa en Castilla en perjuicio de Uclés.

Los santiaguistas suscribieron hermandades con las otras Órdenes, como ya se he dicho, y realizaron deslindes y montanerías, que en su caso se debieron completar con los concejos limítrofes por el este y sur, casos de Alarcón ${ }^{159}$, señorío de Lara, y Alcaraz ${ }^{160}$, primero señorío de la mitra toledana y después real. También propiciaron la extensión del comercio en la zona del Tajo, creando la feria de Fuentidueña ${ }^{161}$, que no prosperó por la oposición del arzobispado de Toledo y, con el apoyo real, canalizaron el tráfico de ganados a lo largo de su campo, entre Ocaña, donde se fijó un portazgo, y el Campo de Montiel. Concedieron fueros de población a algunos lugares, normalmente aplicando el fue-

155 Los lugares poblados a fuero de Consuegra fueron los de Villacañas, Arenas de San Juan, Madridejos, Camuñas, Herencia, Tembleque, Quero, Alcázar de San Juan, Turleque, Villacañas de Algodor y Villaverde. Además la Orden concedió cartas pueblas similares a los lugares de Cedillo y Villar del Pozo. Cfra. Libro de Privilegios de San Juan, 1995, passim.

156 RADES y ANDRADA, F. Chronica de Sanctiago, op. cit. fol. $25 \mathrm{v}^{\circ}$

157 Doc. de fecha 1215, mayo 1. Enrique I confirma al conde don Álvaro Núñez de Lara, la donación en prestimonio vitalicio del castillo de Alhambra hecha anteriormente por la Orden de Santiago, a quien deberá volver dicho castillo a la muerte del conde. Publ. Bullarium... de Santiago doc. 1, p. 61.

158 Publ. Bullarium... de Santiago doc. 1 p. 156.

159 Doc. de fecha 1241, septiembre 28, publ. RIVERA GARRETAS, doc. $\mathrm{n}^{\circ} 179$.

160 Doc. de fecha 1243, febrero 18, publ. Bullarium... de Santiago p. 160.

161 Vid. Rivera GarreTAS, 1985 p. 199 y doc. de fecha 1223, julio 11, publ. Bullarium... de Santiago doc. 1 p. 84.

Hispania, LXII/1, núm. 210 (2002) 9-40 
ro de Uclés y el de Cuenca ${ }^{162}$, y realizaron numerosos contratos de prestimonios y préstamos que afectaron a la gestión de sus castillos y hospitales y también a sus relaciones señoriales con los pequeños labradores, en una modalidad del préstamo rural y constitución de rentas menos conocida ${ }^{163}$. El celo en la defensa de sus intereses señoriales, así como el desarrollo de la vida caballeresca entre sus miembros, que podían casarse y tener hijos, como ya se ha dicho, hizo que este instituto iniciara un proceso señorializador registrado en los documentos con precocidad.

En conclusión, después de las Navas, los dominios de las Órdenes Militares en la Mancha en conjunto comprendían un territorio de cerca de $30.000 \mathrm{~km}^{2}$, sobre los que se asentaba una red de unos 40 castillos, de los que la mitad se encontraba al norte de los Montes de Toledo y en el valle del Tajo, entre Zorita y Toledo. Los documentos de finales del siglo XII nos informan sobre la dotación de estos castillos y su papel en la repoblación de la zona. Como ya hemos dicho más arriba, Alfonso VIII ordenó hacia 1181 que la Orden de Calatrava asignara como dotación a cada uno de sus castillos cuarenta yugadas de tierra ad anni vicem para su mantenimiento, y el resto se repartiera a quiñón entre los pobladores del término. ${ }^{164}$ Por lo tanto, la dotación básica de un castillo sería de 40 yugadas de tierra de labor (1.200 Has aprox.) más unas dehesas propias cuya roturación estaba prohibida. Por otra parte, el quiñón era la unidad de explotación campesina, y equivalía a una yugada de heredad. En esta época un caballero necesitaba disponer del equivalente a 4 yugadas, por lo que es posible deducir que la guarnición básica de un castillo sería de unos diez caballeros que contaría cada uno con la renta de cuatro yugadas respectivamente. Esto nos permite calcular el potencial militar de las Órdenes en la Mancha a principios del siglo XIII en torno a los 400 caballeros, a los que habría que añadir otros 400 escuderos y 800 peones, es decir un total de 1.600 hombres de armas. En este mismo sentido, y como mera conjetura, podemos suponer que la Orden de Santiago tendría en la Mancha algo más de 200 caballeros, la de Calatrava unos $150^{165}$ y la de San Juan alrededor de 50.

${ }^{162}$ El fuero de Uclés se dio a los lugares de Huélamo, Montealegre, Añador y Torrebuceit. Después se extendió por el Campo de Montiel el fuero de Cuenca, mejor adaptado a las condiciones de vida de la frontera por el extraordinario desarrollo de la legislación ganadera que contiene. El primer fuero de Montiel data de 1243 y pertenece a la familia de los fueros de Cuenca.

163 Vid. contrato colectivo de Barcience, doc. de fecha 1223, enero, Publ. Bullarium... de Santiago p. 77.

164 Vid. nota 87.

${ }^{165}$ Los datos aportados son meras conjeturas por el momento; sin embargo, en el caso de Calatrava nuestro cálculo se puede corroborar por la visita del abad Martín de Bithaine, realizada en 1302 , febrero 28 , en la que se dice que, por entonces, en toda la orden, había algo más de 150 
La ganadería fue, por otra parte, una de las principales actividades económicas durante la repoblación de estas tierras. La ocupación de la transierra había favorecido los intereses ganaderos de los grandes concejos situados al norte del sistema central que desarrollaron rutas de trashumancia hacia el Tajo en busca de pastos de invierno, siguiendo prácticas tradicionales en la región de origen remoto. La consolidación de la frontera en esta línea obligó a canalizar el paso de recuas, mandrácoras y rebaños por unos puntos determinados, normalmente junto a los principales castillos de la zona. El incremento del número de cabezas hizo necesario buscar pastizales más amplios en lugares más alejados, por lo que se trazó una red de cañadas por donde se encauzaba este tráfico y se fijaron los portazgos y montazgos.

Alfonso VIII aprobó los primeros portazgos de las Órdenes Militares al sur del Tajo: uno en Consuegra en 1173, para las recuas y ganados que fueran hacia Segura y Alcaraz pasando por Ruidera. También se reguló el tráfico entre Toledo, el puerto de Orgaz, Calatrava la Vieja y Úbeda, y entre Toledo, el puerto de Milagro y Capilla. Los rebaños que circulaban por allí eran los de Segovia y Ávila, como se sabe por los privilegios de las cañadas. ${ }^{166}$ Fernando III quiso limitar el establecimiento de peajes por las Órdenes y reguló los portazgos en la línea del Tajo, por lo que en 1223 fijó tres únicos vados que fueron Zorita, enclave calatravo en tierras de Guadalajara, Alharilla en tierras de Santiago, que daba paso asimismo a Uclés, aunque hay que decir que los santiaguistas también tenían el paso de Oreja, que no se menciona en el documento, y que los dos iniciaron una decadencia por el crecimiento de Ocaña. Y en tercer lugar Toledo, cuyo peaje pertenecía al ayuntamiento de la ciudad. ${ }^{167} \mathrm{~A}$ partir. de entonces el tráfico por los dominios de las Órdenes tiende a canalizarse a través de cuatro rutas. Una oriental que parte de Ocaña, y va hacia el sur hasta enlazar con la cañada que viene de Uclés, después se dirige a Segura y Alcaraz. Por el centro está la ruta de San Juan que parte de Consuegra y se dirige hacia Segura por el este o hacia Alcudia por el oeste. Otra ruta central es la calatrava que por Orgaz va ahora hacia Calatrava la Nueva y se desvía después hacia el oeste para penetrar en Alcudia por Puertollano. La ruta occidental es la toledana que cruza la sierra por Milagro y va por los confines calatravos occidentales por Navas de Estena y Chillón hasta llegar a Alcudia por el oeste. Es significativa la gran coincidencia entre estas rutas y las posteriores cañadas de la Mesta, las conocidas como soriana y segoviana, lo que muestra con toda claridad la importancia de la economía ganadera en la repoblación de esta región y en el desarrollo de las Órdenes Militares.

\footnotetext{
caballeros. AHN Calatrava, docs. Particulares $n^{\circ} 171$. Este dato lo recoge asimismo O'CALLAGHAN, J. «The Affiliation... « op. cit. p. 14.

166 Doc. de fecha 1208, publ. GonZÁlez, 1960, op. cit. vol. III nº 830.

167 Publ. Bullarium... de Santiago, doc. 1, p. 84. 